\title{
EFFECTS OF URBANIZATION ON THE WATER QUALITY OF LAKES IN EAGAN, MINNESOTA
}

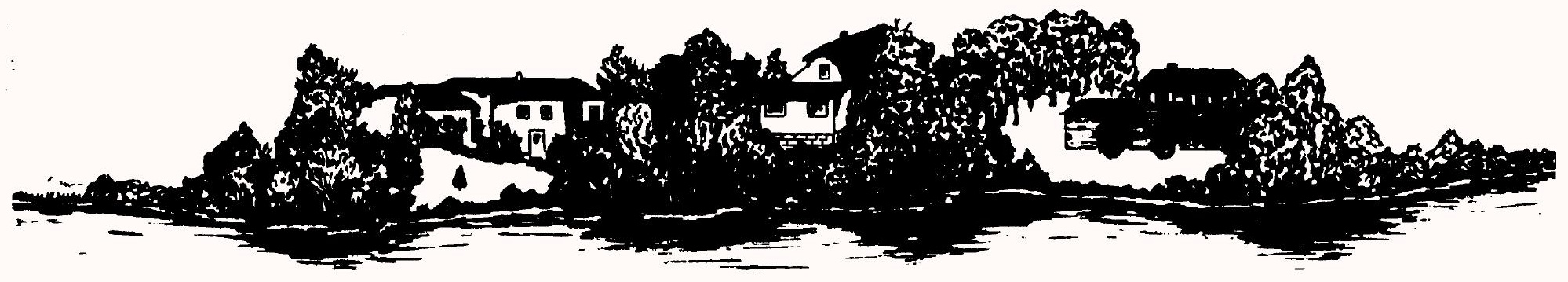

U. S. GEOLOGICAL SURVEY

Water-Resources Investigations 80-71

Prepared in cooperation with the city of Eagan

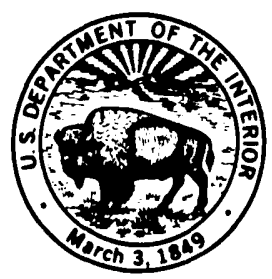


$50272-101$

\begin{tabular}{|c|c|c|}
\hline $\begin{array}{l}\text { REPORT DOCUMENTATION } \\
\text { PAGE }\end{array}$ & 1. REPORT NO. & 3. Recipient's Accession No. \\
\hline \multirow{2}{*}{\multicolumn{2}{|c|}{$\begin{array}{l}\text { 4. Title and subtitle } \\
\text { EF'F'ECTS OF URBANIZATION ON THE WATER QUALTTY OF LAKES IN } \\
\text { EAGAN, MINIJESOTA }\end{array}$}} & $\begin{array}{l}\text { 5. Report Date } \\
\text { August } 1980\end{array}$ \\
\hline & & 6. \\
\hline \multicolumn{2}{|c|}{$\begin{array}{l}\text { 7. Author(s) } \\
\text { Mark A. Ayers, Gregory A. Payne, and Mark R. Have }\end{array}$} & 8. Performing Organization Rept. No. \\
\hline \multirow{2}{*}{\multicolumn{2}{|c|}{$\begin{array}{l}\text { 9. Performing Organization Name and Address } \\
\text { U.S. Geological Survey } \\
\text { Water Resources Division } \\
702 \text { Post Office Building } \\
\text { St. Paul, Minnesota } 55101\end{array}$}} & 10. Project/Task/Work Unit No. \\
\hline & & $\begin{array}{l}\text { 11. Contract(C) or Grant(G) No. } \\
\text { (C) } \\
\text { (G) }\end{array}$ \\
\hline \multirow{2}{*}{\multicolumn{2}{|c|}{$\begin{array}{l}\text { 12. Sponsoring Organization Name and Address } \\
\text { U.S. Geological Survey } \\
\text { Water Resources Division } \\
702 \text { Post Office Building } \\
\text { St. Paul, Ninnesota } 55101\end{array}$}} & 13. Type of Report \& Period Covered \\
\hline & & 14. \\
\hline
\end{tabular}

15. Supplementary Notes

Prepared in cooperation with the city of Eagan

\section{Abstract (Limit: 200 words)}

Water-quality characteristics of 17 lakes and ponds in the city of Eagan were described from data collected from 1972 through 1978. The data showed that differences in water quality between lakes were related to differences in the percentage of urbanization. However, water-quality variations within each lake were affected more by climatic variations than by land-use changes during that period.

Dissolved solids, alkalinity, and chloride concentrations varied most in lakes with urbanized watersheds, in lakes with outlets, and in lakes less than 6 feet deep. Certain lakes without outlets showed an increase in chloride during the study, caused in part by urbanization but intensified by drought conditions of 1976-77.

Fifteen of the lakes studied are less than 10 feet deep and frequently mix during open water. These lakes are highly eutrophic, primarily because of high nutrient loading and recycling of nutrients.

Holland and Fish Lakes, with depths of 52 and 30 feet, respectively, were the least eutrophic. These lakes limit continuous recycling of nutrients from bottm materials to water surface by thermal stratification and entrapment of nutrients in the hypolimnion.

Three phosphorus-prediction models developed during the study are applicable to shallow (less than about 12 feet), nonstratifying lakes and ponds. The data base was not sufficient to select an appropriate model to predict the effects of future loading from continuing urbanization on the deeper lakes.

17. Document Analysis a. Descriptors

*Water quality, *Lakes, *Land use, Eutrophication, Aquatic algae, Chemical properties, Biological properties

b. Identifiers/Open-Ended Terms

*Eagan, *Dakota County, *Minnesota

c. COSATI Field/Group

18. Avallability Statement

No restriction on distribution

\begin{tabular}{|l|l|}
\hline 19. Security Class (This Report) & 21. No. of Pages \\
\hline 20. Security Class (This Page) & 22. Price \\
\hline
\end{tabular}


EFFECTS OF URBANIZATION ON THE

WATER QUALITY OF LAKES IN EAGAN, MINNESOTA

By M. A. Ayers, G. A. Payne, and M. R. Have

U.S. GEOLOGICAL SURVEY

Water-Resources Investigations 80-71

Prepared in cooperation with the city of Eagan

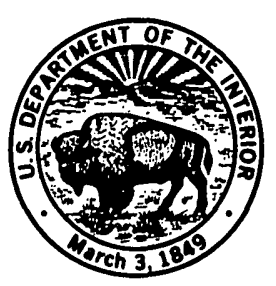


UNITED STATES DEPARTMENT OF THE INTERIOR

CECIL D. ANDRUS, Secretary

GEOLOGICAL SURVEY

H. William Menard, Director

For additional information write to:

U.S. Geological Survey

702 Post Office Bullding

St. Paul, Minnesota 55101 
Conversion factors....................................... iv

Abstract............................................. 1

Introduction........................................... 2

Hydrologic conditions.................................. 2

Methods and approach.................................. 4

Results and discussion................................... 10

Measurements...................................... 10

Inorganic constituents................................ 13

Nutrients........................................ 21

Phosphorus regression model........................... 24

Phosphorus parametric models........................... 25

Troph1c state delineation.............................. 30

Phytoplankton........................................ 34

Summary and conclusions.................................. 38

References.......................................... 40

\section{ILLUSTRATIONS}

F1gure 1. Map showing location of the 17 lakes and ponds studied in Eagan, Minnesota.....................

2. Graph showing mean monthly precipitation and runoff... 5

3. Graph showing mean and range of lake and pond depths at sampling points and mean transparencies and temperature for study lakes.

4. Graph showing temperature and dissolved-oxygen profiles for Fish Lake.

5. Graph showing temperature and dissolved-oxygen profiles for Holland Lake.......................

6. Graph showing mean and range of dissolved solids and chloride and mean alkalinity for study lakes.........

7. Graph showing chloride versus dissolved solids for selected Eagan lakes.

8. Graph showing mean and range of total organic carbon, nitrogen, and phosphorus for study lakes.............

9. Graph showing estimated total phosphorus as a function of percentage of watershed developed and lake volume for shallow, nonstratifying lakes in Eagan.... 


\section{ILLUSTRATIONS}

Page

Figure 10. Graph showing predicted versus observed total phosphorus for the Jones-Bachmann and Reckhow-oxic models....................................... 27

11. Graph showing chlorophyll a versus total phosphorus (summer 1976 data) for study lakes............... 31

12. Graph showing Secchi-disk transparency versus chlorophyll a for study lakes.................... 32

13. Graph showing mean and range of phytoplankton cell count for study lakes.......................... 35

TABLES

Table 1. Type of data collected each water year............. 6

2. Parameters used in statistical and phosphorus model analyses................................ 7

3. Morphometric, land use, soils, and geologic data for the 17 study lakes in Eagan.................... 9

4. General water-quality trends for the 17 study lakes in Eagan....................................... 16

5. Results of phosphorus prediction models............ 28

6. Trophic classification for Eagan lakes............. 33

7. Dominant and codominant algal genera in phytoplankton samples of 17 study lakes in Eagan................ 36

CONVERSION FACTORS

Multiply

\section{inch-pound unit}

Inch (in)

foot ( $f t$ )

mile (mI)

acre
By

25.4

0.3048

1.609

4047
To obtain SI unit

millimeter (m)

meter (m)

kilometer $(\mathrm{km})$

square meter $\left(\mathrm{m}^{2}\right)$ 
EFFECTS OF URBANIZATION ON THE WATER QUALITY

OF LAKES IN EAGAN, MINNESOTA

By Mark A. Ayers, Gregory A. Payne, and Mark R. Have

\section{ABSTRACT}

Water-quality characteristics of 17 lakes and ponds in the city of Eagan were described from data collected from 1972 through 1978. The data showed that differences in water quality between lakes were related to differences in the percentage of urbanization. However, water-quality variations within each lake were affected more by climatic variations than by land-use changes during that period.

Dissolved solids, alkalinity, and chloride concentrations varied most in lakes with urbanized watersheds, in lakes with outlets, and in lakes less than 6 feet deep. Certain lakes without outlets showed an increase in chloride during the study, caused in part by urbanization but intensifled by drought conditions of 1976-77.

Fifteen of the lakes studied are less than 10 feet deep and frequently mix during open water. These lakes are highly eutrophic, primarily because of high nutrient loading and recycling of nutrients.

Holland and Fish Lakes, with depths of 52 and 30 feet, respectively, were the least eutrophic. These lakes limit continuous recycling of nutrients from bottom materials to surface waters by thermal stratification and entrapment of nutrients in the hypolimnion.

Three phosphorus-prediction models developed during the study are applicable to shallow (less than about 12 feet), nonstratifying lakes and ponds. One model, derived from a multiple-regression analysis, uses the percentage of the watershed developed and lake volume to predict phosphorus concentrations. The other models use phosphorus settling and flushing or retention coefficients to determine phosphorus concentrations in lakes from an estimated average annual phosphorus load. The data base was not sufficient to select an appropriate model to predict the effects of future loading from continuing urbanization on the deeper lakes. 


\section{INIRODUCTION}

The city of Eagan is located in northern Dakota County, southeastern Minnesota (fig. 1). The physiography is dominated by the St. Crolx moraine complex formed during Wisconsin Glaciation (Wright, 1972). The part of the complex within Eagan's corporate boundaries contains more than 100 small lakes and ponds.

In the late 1950's, Eagan began changing from a rural township to a suburban community. At present (1979), Eagan consists of small farms, parks, residential developments, shopping centers, business districts, and industrial parks. It is one of the fastest growing cities in the Twin Cities metropolitan area.

Lack of information about the effects of urban development on water quality of the lakes and ponds was a matter of concern to the community. In 1971, the U.S. Geological Survey at the request of the city of Eagan designed a program to monitor the water quality in selected lakes. The purpose of the monitoring was to establish baseline water-quality data from which to observe changes in quality resulting from urbanization.

Chemical and biological sampling in 17 selected lakes and ponds began In October 1972. A report by Have (1975) describes the activities and findings of the first 2 years of study. Monitoring has continued through October 1978. The purpose of this report is to (1) further describe the water quality of the lakes, (2) identify water-quality changes during the period of study, and (3) relate such changes or differences in the lakes to changing land use so that city officials can choose design alternatives that will minimize the impact of future growth on lake quality.

\section{Hydrologic Conditions}

The lakes in the Eagan area are in closed basins within the hummocky, generally sandy moraine deposits. The area lacks well-defined surface drainage patterms. Larger drainage basins contain numerous subbasins, which also drain internally to small ponds or marshes. Therefore, areas contributing surface munoff directly to individual lakes are not easily definable. Most lakes are connected to the local ground-water system, but the inflowoutflow relationship is unknown. For simplification of phosphorus-loading estimates, it was assumed that ground-water inflow balances outflow and that phosphorus contributed by ground water was negligible.

Development related to urbanization has increased surface runoff to many lakes. Most lakes and depressions have been incorporated in the Eagan Comprehensive Storm Sewer Plan (Bonestroo and others, 1978) in order to help control storm runoff. Storm-sewer outlets are generally necessary for controlling maximum lake levels in highly urbanized watersheds of the Eagan area. Storm-sewer inlets and outlets are planned for most lakes; some lakes already have them. Hence, increased development has also led to increased hydrologic complexity of these lake systems. 


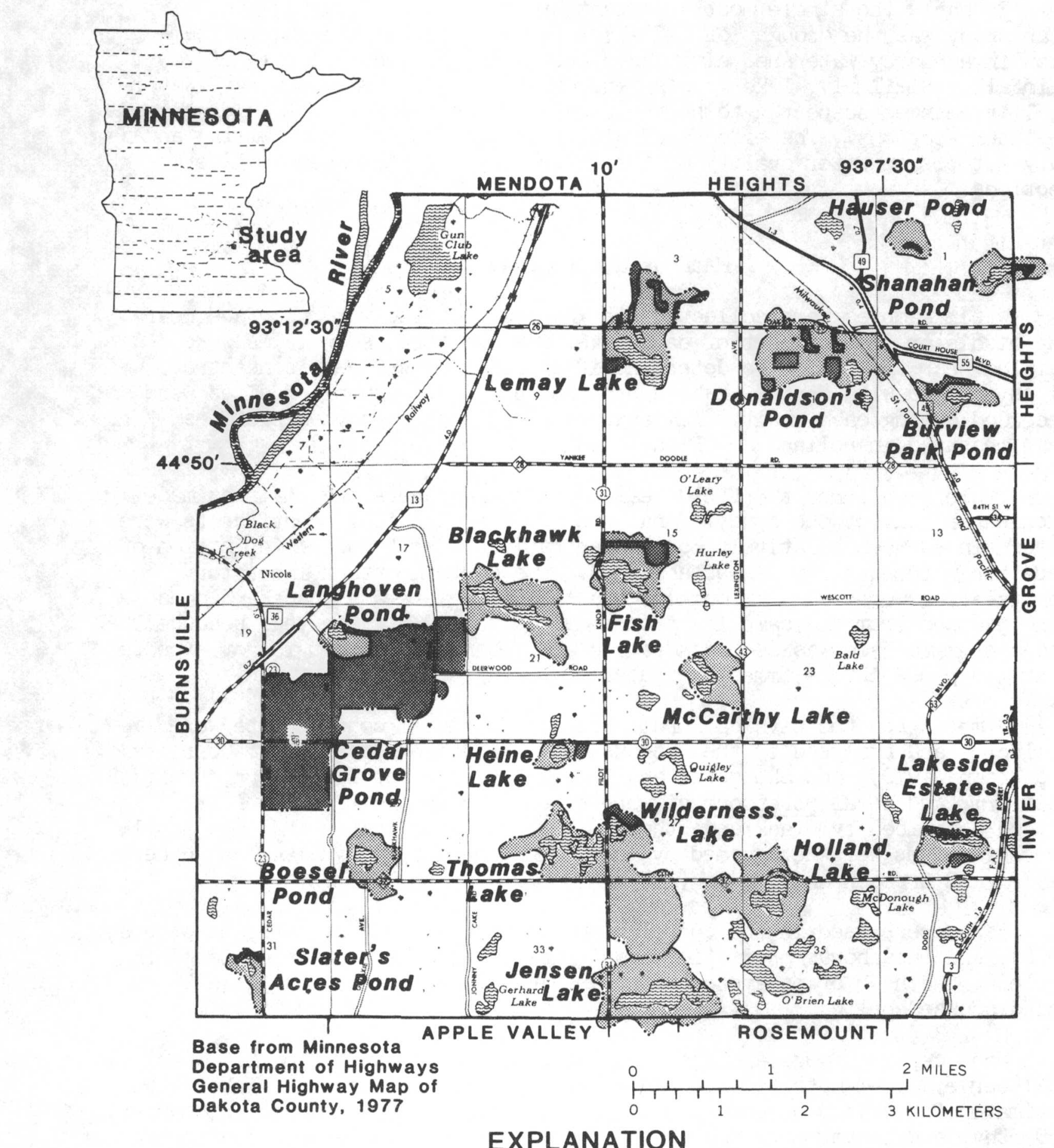

EXPLANATION 
Probably the single most important hydrologic event during the 6year study was the drought of 1976-77. Figure 2 illustrates how streamflow in a nearby watershed diminished during the prolonged period of low rainfall. Similarly, lake levels generally declined. Some observed waterquality changes suspected to be the result of the drought will be discussed in later sections. The effects of winter ice cover, spring snowmelt, and large storms on water quality of the lakes are also discussed in later sections.

\section{Methods and Approach}

Water samples were collected within 3 feet of the water surface near the middle or deepest part of each lake. In addition, some lakes were sampled near the bottom to determine if selected constituent concentrations changed with depth. Lake depths at each of the sampling sites were recorded during each visit. Temperature and dissolved-oxygen profiles were measured in Holland and Fish Lakes.

Table 1 outlines the field measurements and laboratory analyses made each water year of the study. Analyses for some chemical constituents were discontinued when relatively low concentrations were found or definition of baseline water quality was established. The most important laboratory analyses were continued throughout the study. Hauser and Shanahan Ponds were dropped from the sampling program after the 1976 water year because the baseline-data base was deemed adequate and urban development is not expected near the ponds in the immediate future.

Samples for the physical properties and chemical constituents were collected and analyzed by the methods of Brown and others (1970), Goerlitz and Brown (1972), and Skougstad and others (1978). Total coliform, fecal coliform, and fecal Streptococcl were determined by the membrane-filter method described by Slack and others (1973). Phytoplankton and chlorophyll concentrations were determined by the methods described by Slack and others (1973) and Greeson and others (1977).

Parameters used in the correlation, linear regression (Barr and others, 1976), and phosphorus prediction model analyses in the study are listed in table 2. Methods of parameter determination are also given in table 2, or are discussed below.

Mean depths of Holland and Fish Lakes were calculated from U.S. Geological Survey 7.5-minute topographic maps. Mean depths for other lakes were estimated from field observations. The shallowest lakes, Langhoven, Hauser, McCarthy, and Slater's Acres, were assumed to have mean depths equal to the mean maximum depth over the study period because of their virtually flat 


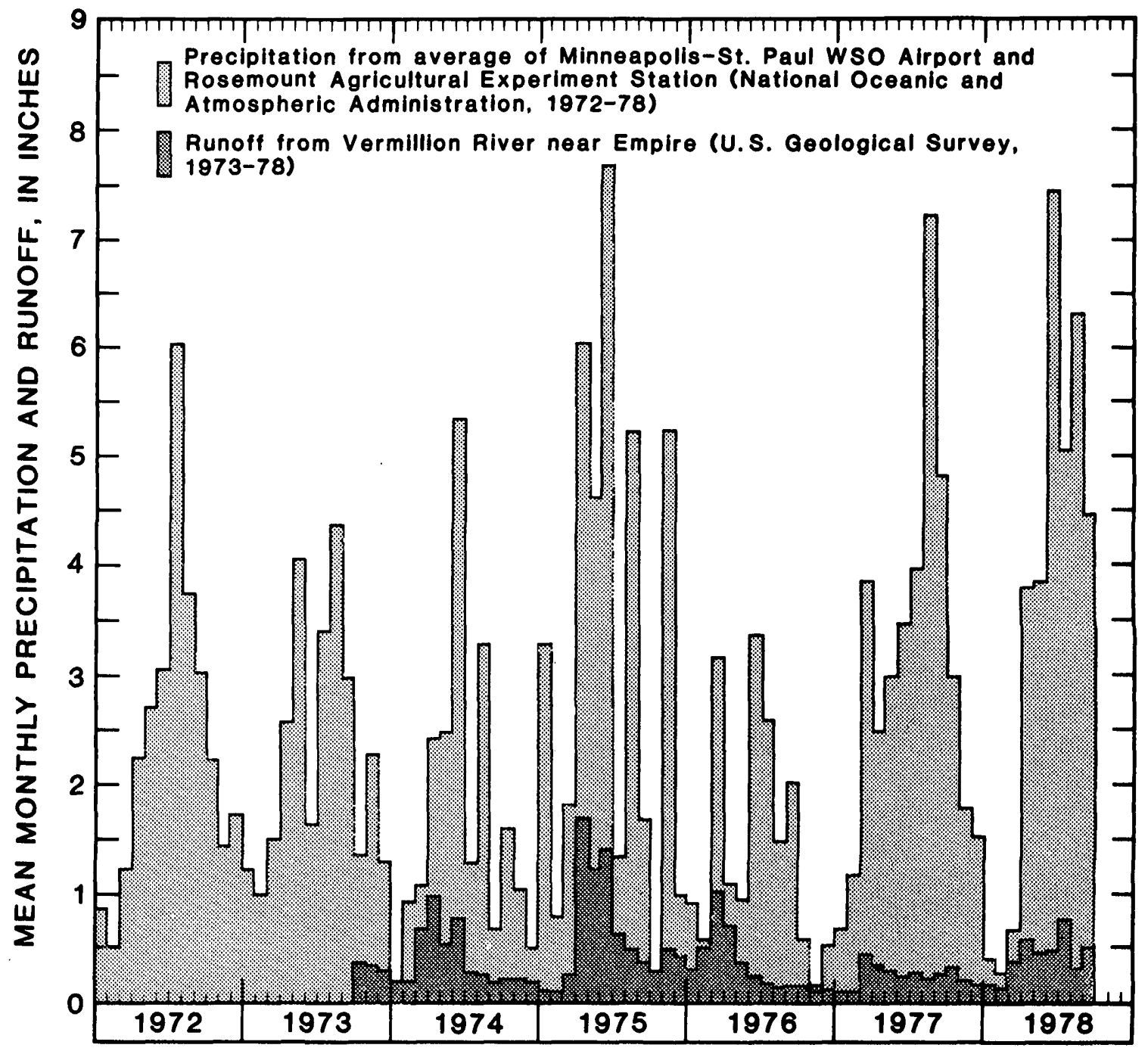

Figure 2.--Mean monthly precipitation and runoff 
Table 1.--Type of data collected each water year

\begin{tabular}{|c|c|c|c|c|c|c|}
\hline CONSTITUENT & 1973 & 1974 & $\begin{array}{l}\text { WATER } \\
1975\end{array}$ & $\begin{array}{l}\text { YEAR } \\
1976 \\
\end{array}$ & 1977 & 1978 \\
\hline Water temperature....... & $\mathrm{x}$ & $\mathbf{x}$ & $\mathbf{x}$ & $\mathbf{x}$ & $\mathbf{x}$ & $\mathbf{X}$ \\
\hline Depth at sampling point............ & $\mathbf{x}$ & $\mathbf{x}$ & $\mathbf{x}$ & $\mathrm{x}$ & $\mathbf{x}$ & $\mathbf{x}$ \\
\hline Specific conductance............... & $\mathbf{x}$ & $\mathrm{x}$ & $\mathbf{x}$ & $\mathrm{x}$ & $\mathrm{x}$ & $\mathbf{x}$ \\
\hline Dissolved oxygen.................. & $\mathbf{x}$ & $\mathbf{x}$ & $\mathbf{x}$ & $\mathbf{x}$ & $\mathbf{x}$ & $\mathbf{x}$ \\
\hline pH............................ & $\mathrm{x}$ & $\mathbf{x}$ & $\mathbf{x}$ & $\mathbf{x}$ & $\mathrm{x}$ & $\mathrm{x}$ \\
\hline Secch1 disk transparency............ & - & - & - & $\mathbf{x}$ & $\mathbf{x}$ & $\mathrm{x}$ \\
\hline 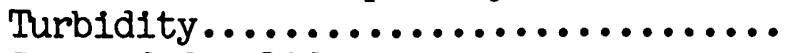 & $\mathrm{x}$ & $\mathrm{x}$ & $\mathrm{x}$ & $\mathrm{x}$ & $\mathrm{x}$ & $\mathrm{x}$ \\
\hline Suspended solids................. & $\mathrm{x}$ & $\mathbf{x}$ & $\mathbf{x}$ & $\mathrm{x}$ & - & - \\
\hline Dissolved solids................. & $\mathbf{x}$ & $\mathrm{x}$ & $\mathbf{x}$ & $\mathbf{x}$ & $\mathbf{x}$ & a \\
\hline Alkalinity as calcium carbonate...... & $\mathrm{x}$ & $\mathbf{x}$ & - & $\mathrm{x}$ & - & $-\infty$ \\
\hline Dissolved calcium................. & $\mathrm{x}$ & $\mathbf{x}$ & - & - & - & - \\
\hline Dissolved magnesium.............. & $\mathbf{x}$ & $\mathbf{x}$ & - & - & - & - \\
\hline Dissolved sodium................. & $\mathbf{x}$ & $\mathrm{x}$ & - & - & - & - \\
\hline Dissolved potassium............... & $\mathbf{x}$ & $\mathrm{x}$ & - & - & - & - \\
\hline 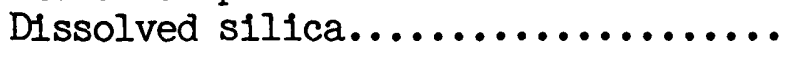 & $\mathrm{x}$ & $\mathrm{x}$ & 一 & - & 一 & - \\
\hline Dissolved chloride............... & $\mathbf{x}$ & $\mathrm{x}$ & $\mathbf{x}$ & $\mathbf{x}$ & $\mathbf{x}$ & $\mathbf{x}$ \\
\hline Total organic nitrogen as N......... & $\mathbf{x}$ & $\mathbf{x}$ & - & 一 & - & - \\
\hline Total ammonia as N................ & $\mathbf{x}$ & $\mathrm{x}$ & - & - & - & 一 \\
\hline Total ammonia plus organic as N...... & - & - & $\mathrm{x}$ & $\mathbf{x}$ & - & - \\
\hline Total nitrite plus nitrate as N...... & $\mathbf{x}$ & $\mathbf{x}$ & $\mathbf{x}$ & $\mathrm{x}$ & 一 & - \\
\hline Total nitrogen...... & $\mathrm{x}$ & $\mathbf{x}$ & $\mathrm{x}$ & $\mathbf{x}$ & - & - \\
\hline Total phosphorus.................. & $\mathbf{x}$ & $\mathrm{x}$ & $\mathbf{x}$ & $\mathrm{x}$ & $\mathbf{x}$ & a \\
\hline Dissolved phosphorus............. & $\mathrm{x}$ & $\mathrm{x}$ & - & - & - & - \\
\hline Dissolved orthophosphate as P........ & $\mathrm{x}$ & $\mathrm{x}$ & $\mathrm{x}$ & $\mathbf{x}$ & - & - \\
\hline 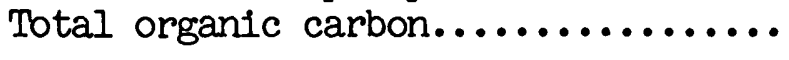 & - & - & $\mathbf{x}$ & $\mathrm{x}$ & - & - \\
\hline B1ochemical oxygen demand.. & $\mathbf{x}$ & $\mathbf{x}$ & - & - & - & - \\
\hline Total nitrogen in bottom material.... & - & - & $\mathrm{x}$ & $\mathrm{x}$ & - & - \\
\hline Total phosphorus in bottom material.. & - & - & $\mathrm{x}$ & $\mathbf{x}$ & - & - \\
\hline Organic carbon in bottom material.... & - & - & 一 & $\mathbf{x}$ & 一 & - \\
\hline Phytoplankton (genus level)......... & $\mathbf{x}$ & $\mathbf{x}$ & $\mathbf{x}$ & $\mathrm{x}$ & $\mathrm{x}$ & a \\
\hline Chlorophyll a and $\underline{b}$. & - & - & - & $\mathbf{x}$ & $\mathrm{x}$ & a \\
\hline Total coliform................. & $\mathrm{x}$ & $\mathrm{x}$ & - & - & - & - \\
\hline Fecal coliform................. & $\mathbf{x}$ & $\mathrm{x}$ & $\mathbf{x}$ & 一 & - & - \\
\hline Fecal Streptococci................. & - & - & $\mathbf{x}$ & - & - & - \\
\hline
\end{tabular}

a Holland and Fish Lakes only. 
Table 2.--Parameters used in statistical and phosphorus model analyses

Parameter

Abbreviation

Method of Determination

Water-quality parameters

Water-quality constituents (table A)

C:N Ratio in lake.................... CNRATIO

$\mathrm{N}: \mathrm{P}$ Ratio in lake.................. NPRATIO

C:N Ratio in bottom materials.......... CNBTM

$\mathrm{N}: \mathrm{P}$ Ratio in bottom material.......... NPBTM

Mean for study period

TOC/TN

TN/TP

OCBTM/NBTM

NBTM/PBTM

Morphometric parameters

Drainage area (acres).............. DA

Lake area (acres)................. LA

Lake area, percent................ LAP

Lake depth, maximum (feet)........... DEPTH

Lake depth, mean (feet)............. ZF

Lake volume (acre-feet)............. VOL

Shoreline length (miles).............. SL

Shoreline configuration............... SLC

Shoreline vegetation (miles)........... SLIT

Undeveloped area (acres).............. UND

Undeveloped area percent............ UNDP

Developed area (acres)............... DEV

Developed area percent............... DEVP
USGS 7.5-minute topographic maps (see text)

USGS 7.5-minute topographic maps (LA/DA)*100

Mean of field measurements

Estimated, see text

$L A * Z F$

USGS 7.5-minute topograph1c maps Wetzel, 1975, page 31 Estimated percent *SL see text

(UND/DA)*100

see text

$(\mathrm{DEV} / \mathrm{DA}) * 100$

-- Runoff and phosphorus load parameters, see text -

Precfipitation, mean annual for study

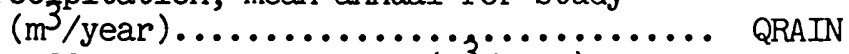

Runoff, undeveloped area $\left(\mathrm{m}^{3} /\right.$ year $) \ldots .$. Q.. QUND

Runoff, developed area (m $3 /$ year)........ QDEV

Runoff, direct precipitation ( $3 /$ year)... QDP

29.92 inches*DA*102.8

(UNDP/100)*QRAIN*0.1

(DEVP $/ 100) *$ QRAIN*0.25

Runoff, total to lake (m $\mathrm{m}^{3}$ year)........ QIOT

(LAP/100)*QRAIN

QUND + QDEV + QDP

Phosphorus load, undeveloped (mg/year)... LUP

Phosphorus load, developed (mg/year)..... LDP

Phosphorus load, precipitation (mg/year). LPP

Phosphorus load, total (mg/year)........ FLUXP

QUND*290 $\mathrm{mg} / \mathrm{m}_{3}^{3}$

QDEV*600 $\mathrm{mg} / \mathrm{m}^{3}$

$\mathrm{QDP} * 38 \mathrm{mg} / \mathrm{m}^{3}$

Phosphorus load per unit lake area

$\left[\left(\mathrm{mg} / \mathrm{m}^{2}\right) /\right.$ year $] \ldots \ldots \ldots \ldots \ldots \ldots \ldots \ldots \ldots$ LOADP

LUP + LDP + LPP

Runoff per unit lake area (m/year)

Runoff per unit lake volume (1/year)

QS QTOT/(LA*4047)

RHO QTOT/(VOL*1234)

- Alternate phosphorus load parameters, Smith, 1979 -

Phosphorus load, undeveloped (mg/year)... LUS

Phosphorus load, developed (mg/year)..... LDS

Phosphorus load, precipitation (mg/year). LPS

Phosphorus load, total (mg/year)........ FLUXPS

Phosphorus load per unit lake area

$\left[\left(\mathrm{mg} / \mathrm{m}^{2}\right) /\right.$ year $] \ldots \ldots \ldots \ldots \ldots \ldots \ldots \ldots \ldots \ldots$ LOADPS

$(\mathrm{UND} * 4047) * 23\left(\mathrm{mg} / \mathrm{m}^{2}\right) /$ year

$(\mathrm{DEV} * 4047) * 110\left(\mathrm{mg} / \mathrm{m}^{2}\right) /$ year

$\left(\mathrm{LA}^{*} 4047\right) * 29\left(\mathrm{mg} / \mathrm{m}^{2}\right) /$ year

LUS + LDS + LPS

FLUXPS/(LA*4047) 
bottoms. Jensen Lake, which is shallow but considerably larger in area, was assumed to have a mean depth equal to 90 percent of the mean maximum depth. The rest of the lakes, which are somewhat deeper, were assumed to have a mean depth of 80 percent of the mean maximum depth.

That part of the watershed which contributes surface munoff to the lakes was determined for this study. All internal drainage depicted on the topographic maps as marshes, hollows, or small ponds within the natural or urban modified watersheds were considered noncontributing and were deleted. Drainage areas for urban or other types of development were then included as calculated from both topographic and Eagan storm-sewer maps (Bonestro and others, $1975 ; 1978)$. Lake area also was included in the total drainage area. Land-use acreages and percentages were then calculated as undeveloped, developed, and lake area. The morphometric, land use, soils, and geologic data for each of the 17 study lakes are summarized in table 3.

Mean annual precipitation was calculated from mean monthly averages for the Minneapolis-St. Paul WSO Airport and Rosemount Agricultural Experimental Station data (National Oceanic and Atmospheric Administration, 1972-78) for September 1972 through August 1978. The average annual precipitation during this 6-year period, based on the year from September through the following August, was 29.92 inches.

Mean annual surface runoff (same year as precipitation) was then estimated for undeveloped and developed areas by applying runoff coefficients of 0.10 and 0.25 , respectively. The coefficient for undeveloped areas was estimated from an analysis of mean annual surface runoff for a nearby stream, Vermillion River at Empire (U.S. Geological Survey, 1973-78). The surface runoff coefficient was estimated to be half of the coefficient used in the Eagan Comprehensive Storm Sewer Plan (Bonestroo and others, 1978), which is considered to be a reasonable adjustment of the coefficient for an annual basis rather than the 5- to 10-year basis used for storm-sewer design. The coefficients used for developed areas in the storm-sewer plan ranged from 0.4 to 0.6 (about 0.5). Similarly, coefficients used for developed areas were assumed for this study to be about half (0.25) of the storm-sewer coefficient.

Neglecting ground water, the total munoff to a lake was calculated as the sum of direct precipitation and munoff from undeveloped and developed areas. Flushing coefficients, (QS and RHO, table 2) were then calculated with appropriate morphometric parameters.

Phosphorus loads for each lake were estimated using values of average phosphorus concentrations from a report by Oberts and Jouseau (1979) and calculated runoff for each land use. Loads were also calculated by a method described by Smith (1979). Results from both methods agreed within about 10 percent. 


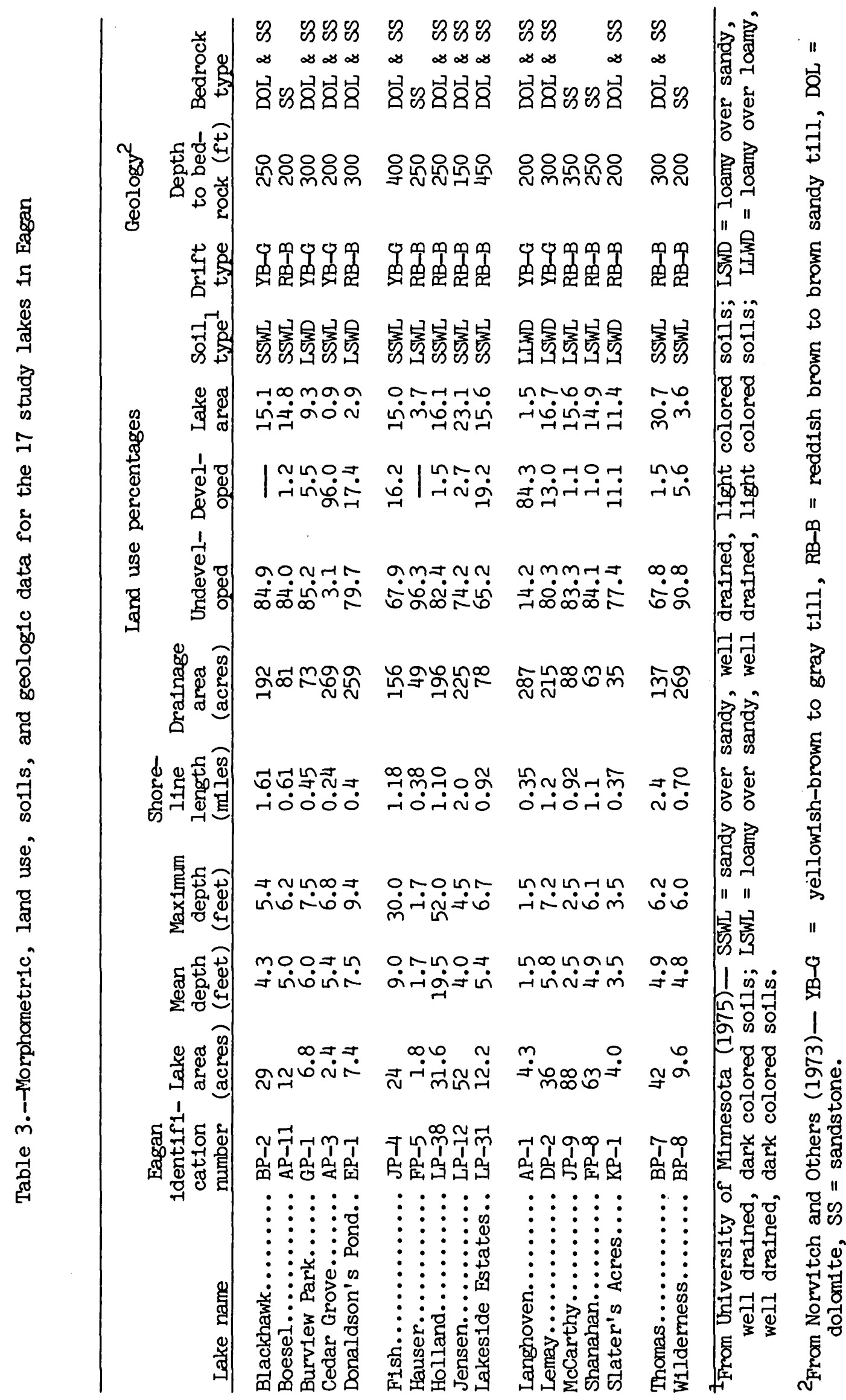




\section{RESULTS AND DISCUSSION}

\section{Measurements}

The 17 lakes in the study area ranged in size from 1.8 (Hauser) to 52.0 acres (Jensen), and in depth from 1.5 (Langhoven) to 52 (Holland) feet (fig. 3 and table.3). Only Holland and Fish Lakes are deep enough to develop thermal stratification. All other lakes are less than 10 feet deep and frequently $y$ ix during open-water conditions, mainly in response to changes in heating, cooling, and wind. A thermal gradient develops in all lakes under ice cover $\left(0.0^{\circ} \mathrm{C}\right.$ top to $4.0^{\circ} \mathrm{C}$ bottom).

Temperature and dissolved-oxygen profiles measured in Holland and Fish Lakes indicate thermal stratification during warm months with anaerobic conditions in the hypolimnion (figs. 4 and 5). Surface cooling and mixing resulted in complete tumover by late fall and the development of aeroblc conditions (about 60 percent of saturation) throughout the profile. Continued cooling during fall and winter brought on ice cover and a period of winter stagnation. Oxygen was again depleted in deeper waters through decay processes, and by spring much of the profile was anaerobic. Melting of the ice cover in spring caused another tumover, with partial mixing in Holland (to a depth of about 40 feet) and generally complete mixing in Fish Lake. However, data collected in April 1979 indicate that Fish Lake may not completely tumover every spring. Further warming in spring results in strong thermal stratification by late spring, then the cycle repeats.

Some anomalies in dissolved-oxygen concentrations were observed during summer. Eplilmnetic waters were only 50 to 70 percent saturated with dissolved oxygen during July and August 1976 (Holland) and in late August 1978 (both Holland and Fish). The low dissolved oxygen in 1976 may be due to measurements made in the morning (about 0900 and 1130 hours, respectively) before recovery from algal respiration during the previous night. Other factors, such as the effect of the drought, relatively high temperatures, or dieoff of algae from a previous bloom may also have contributed to the 1976 anomalies. The low epilimnetic oxygen concentrations in August 1978 likely resulted from a shock-loading effect (either toxic, organic, or by dilution) of a 5- to 6-inch rainstorm the week previous to the sampling. Similarly low dissolved-oxygen concentrations were found in most other area lakes. The followup profiles in Holland and Fish (September 6, 1978) show a recovery to normal oxygen conditions, probably in response to a recovery of the phytoplankton community.

Another anomalous dissolved-oxygen profile was observed in Fish Lake on July 29, 1976. A concentration of about 200 percent of saturation was observed in the upper zone of the metalimion (11 to 14 feet deep), presumably in response to a trapping of oxygen produced by phytoplankton during photosynthesis within the density gradient of the thermocline. A secchi disk reading of 14.3 feet indicates that photosynthesis could indeed be supported at that depth. 


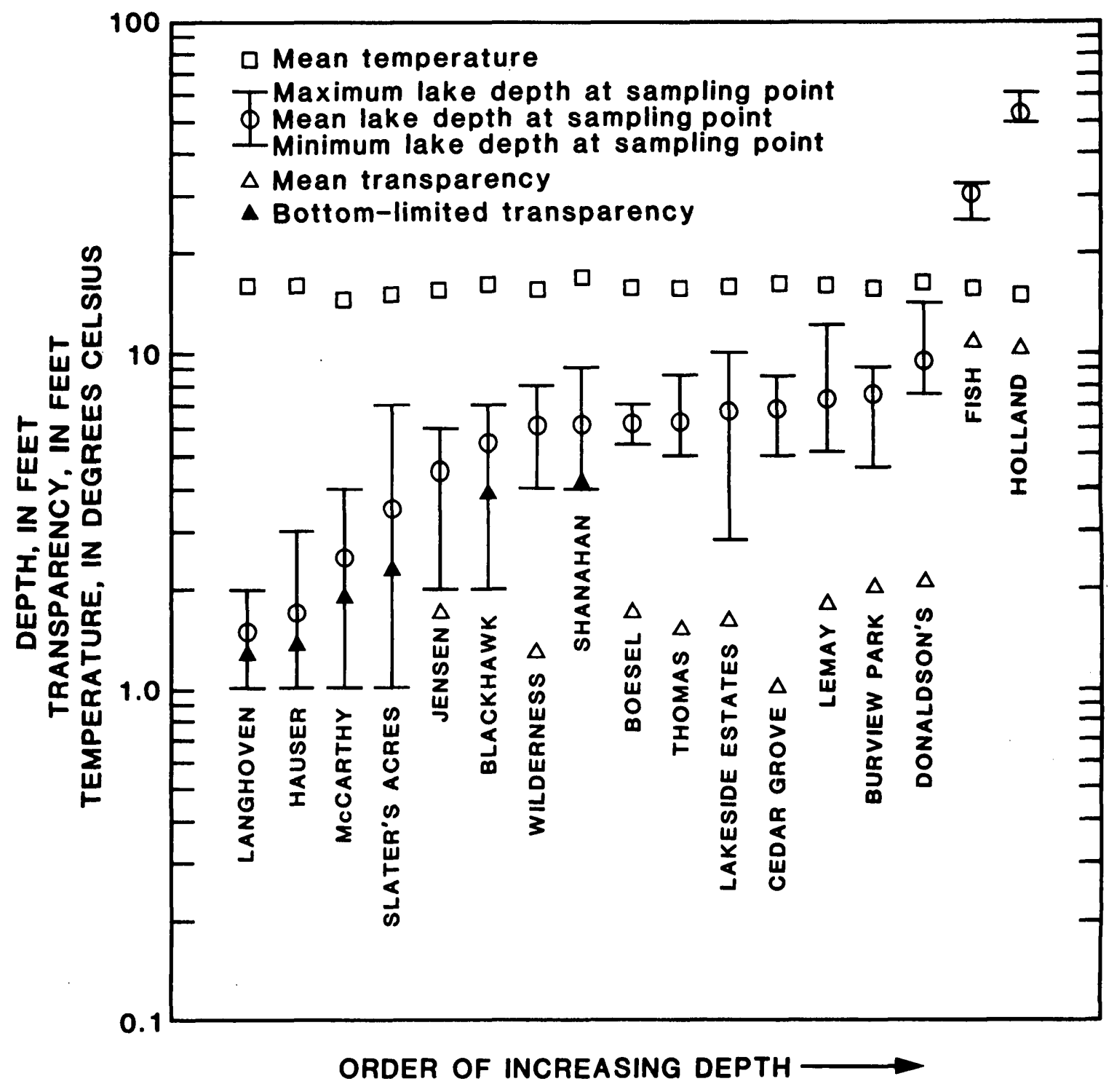

Figure 3.--Mean and range of lake and pond depths at sampling polnts and mean transparencles and temperature for study lakes 

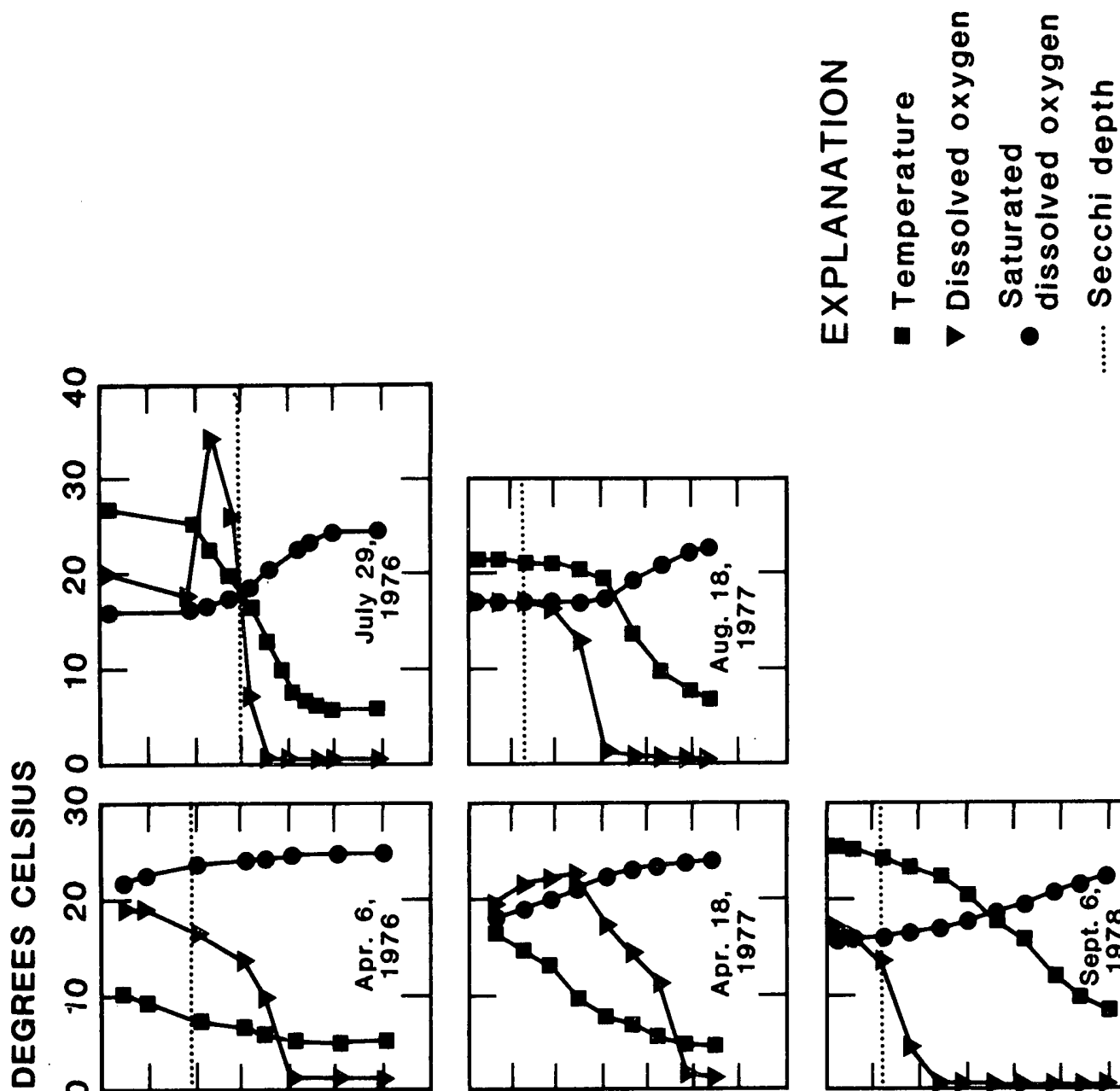

क
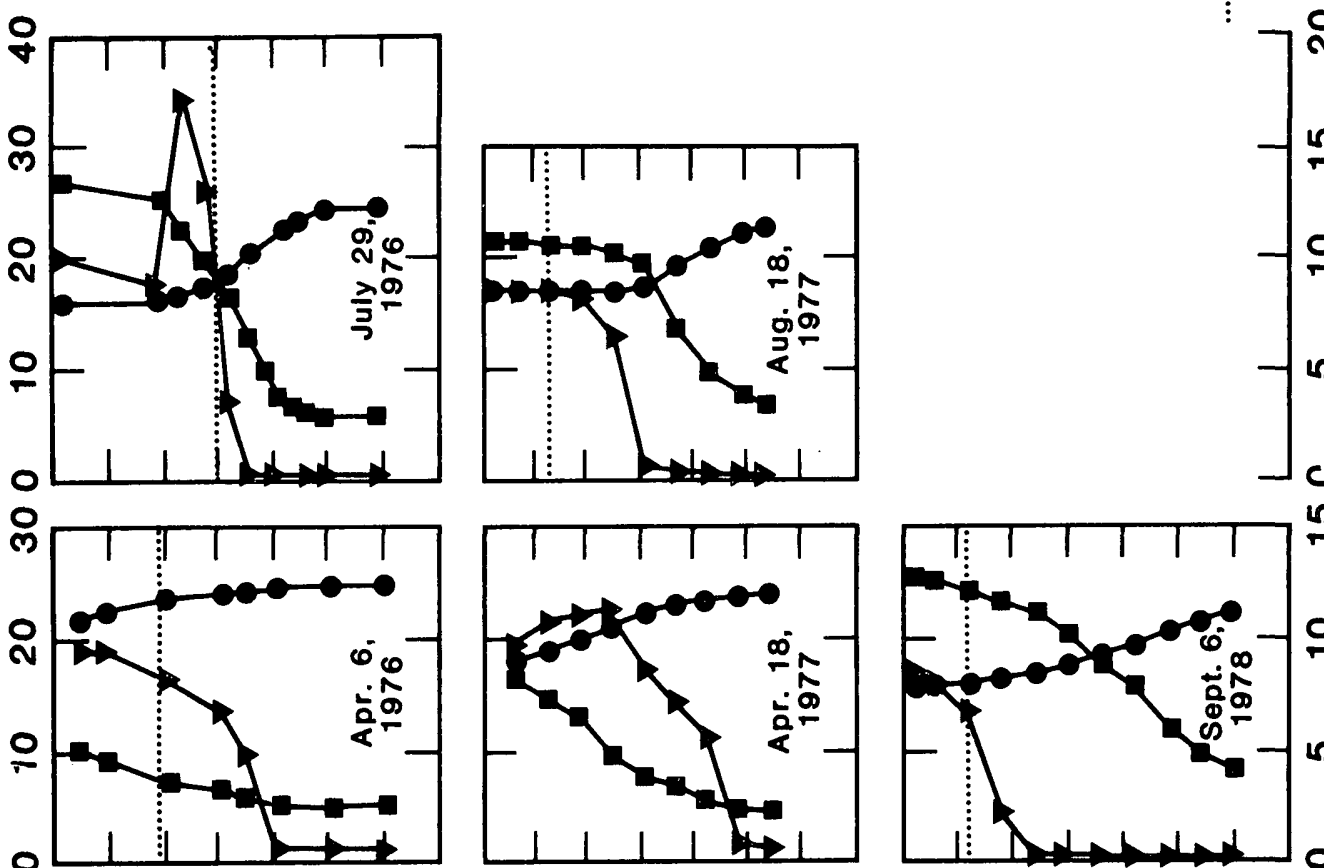

5

2

崩
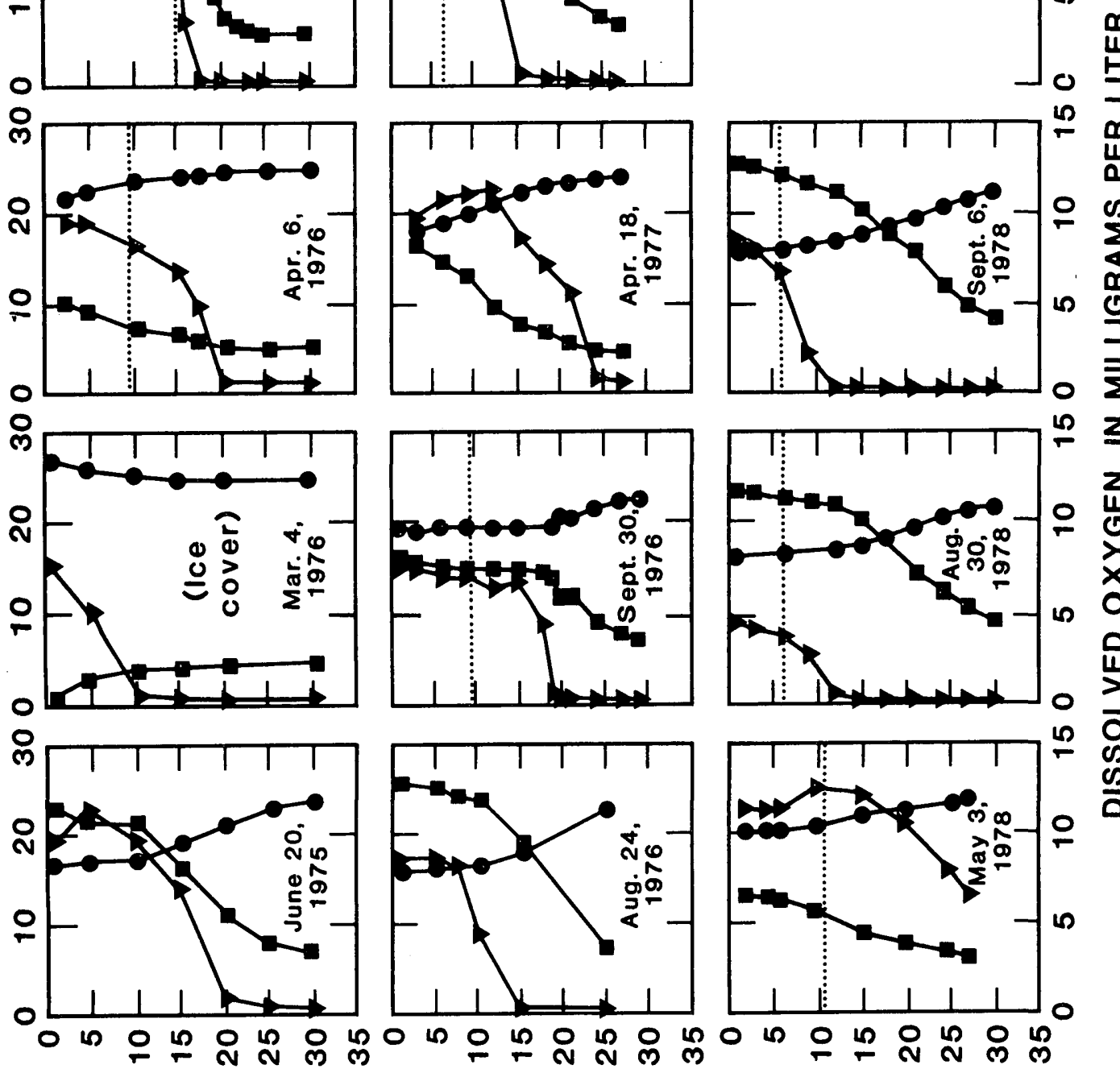

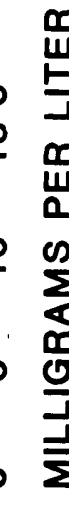
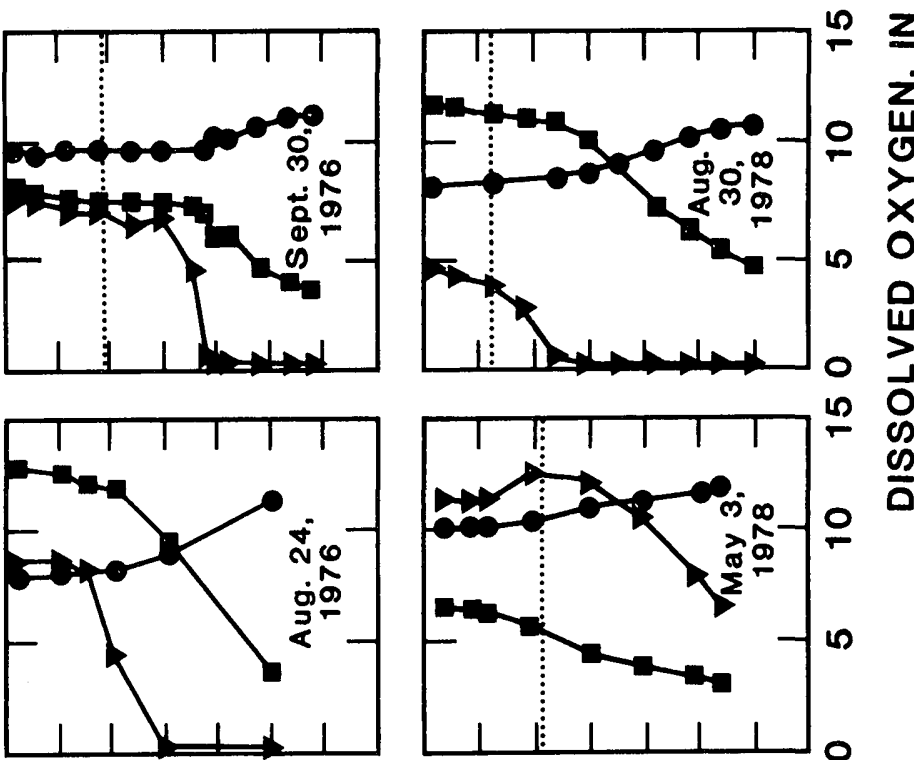

$\frac{1}{8}$

$\perp \exists \exists \unlhd N I ' H \perp d \exists O$ 
Dissolved oxygen in the shallower lakes is generally near saturation throughout most of the year, with concentrations varying mainly in response to temperature and biologic activity. Dissolved-oxygen concentrations below $5.0 \mathrm{mg} / \mathrm{L}$ were observed under ice cover during February to March 1976 in Blackhawk, Boesel, Donaldson's, Hauser, Jensen, Lakeside Estates, Langhoven, McCarthy, Shanahan, and Slater's Acres (table 4). All these lakes are less than 7.0 feet deep. Cedar Grove, Wilderness, and Thomas are also less than 7.0 feet deep and are highly eutrophic but, surprisingly, the dissolvedoxygen concentrations in these three lakes were higher than in the other shallow lakes. Oxygen levels below $5.0 \mathrm{mg} / \mathrm{L}$ were also found in some of the very shallow (1 to 2 feet deep) lakes during July and August 1976 (table 4). These low oxygen concentrations are likely due, in part, to the very high water temperatures and low water levels associated with the drought and perhaps to benthic oxygen demand, as the lowest oxygen levels were associated with the shallowest lakes. The cause of other dissolved-oxygen concentrations less than $5.0 \mathrm{mg} / \mathrm{L}$ occasionally found in some lakes is unknown.

Mean transparencles (secch1 disk) of the Eagan lakes ranged from 1.0 foot in Cedar Grove Pond to 10.8 feet in Fish Lake (fig. 3). Mean transparencles for Langhoven, Hauser, McCarthy, Slater's Acres, Blackhawk, and Shanahan (fig. 3 and table 4) are mostly a function of lake depth; much greater transparencies would be measured if the lakes were deeper. Algal populations were the dominant factor for low transparencies ( 1 to 2 feet) in lakes that receive above-normal loadings of phosphorus from urban or other non-point related sources (table 4). These low-transparency lakes also showed a distinct decrease in transparency from spring to summer (table 4) owing to denser algal populations during the warmer months.

The mean lake-surface temperature for all observations during the study period ranged from $14.5^{\circ} \mathrm{C}$ in McCarthy to $16.7^{\circ} \mathrm{C}$ in Shanahan (fig. 3). The maximum observed surface temperature ranged from $25.0^{\circ} \mathrm{C}$ in Hauser and Holland to $30.0^{\circ} \mathrm{C}$ in Langhoven. No significant correlations could be found between temperature and the geomorphic variables used in this study. Therefore, the temperature differences of these lakes are probably a function of subtle differences in factors controlling heating and cooling not explainable by simple morphologic characteristics such as lake depth.

\section{Inorganic Constituents}

Calcium and bicarbonate dominated the ionic composition of all lakes sampled. The mean dissolved-solids concentration ( $\mathrm{fig} .6$ ) ranged from 87 (Boesel) to $188 \mathrm{mg} / \mathrm{L}$ (Lemay). The mean alkalinity (as $\mathrm{CaCO}_{3}$ ) ranged from 43 (Cedar Grove) to $156 \mathrm{mg} / \mathrm{L}$ (McCarthy). Alkalinity tended to be a lower proportion of dissolved solids in lakes affected by urbanization especially in those lakes with storm-sewer inlets and outlets (Cedar Grove, Donaldson's, and Lemay), presumably because of more impervious area runoff and proportionately less soil-buffered runoff. The highest mean chloride concentrations (25 to $33 \mathrm{mg} / \mathrm{L}$ ) were also associated with these three lakes. Lakes 
TEMPERATURE, IN DEGREES CELSIUS

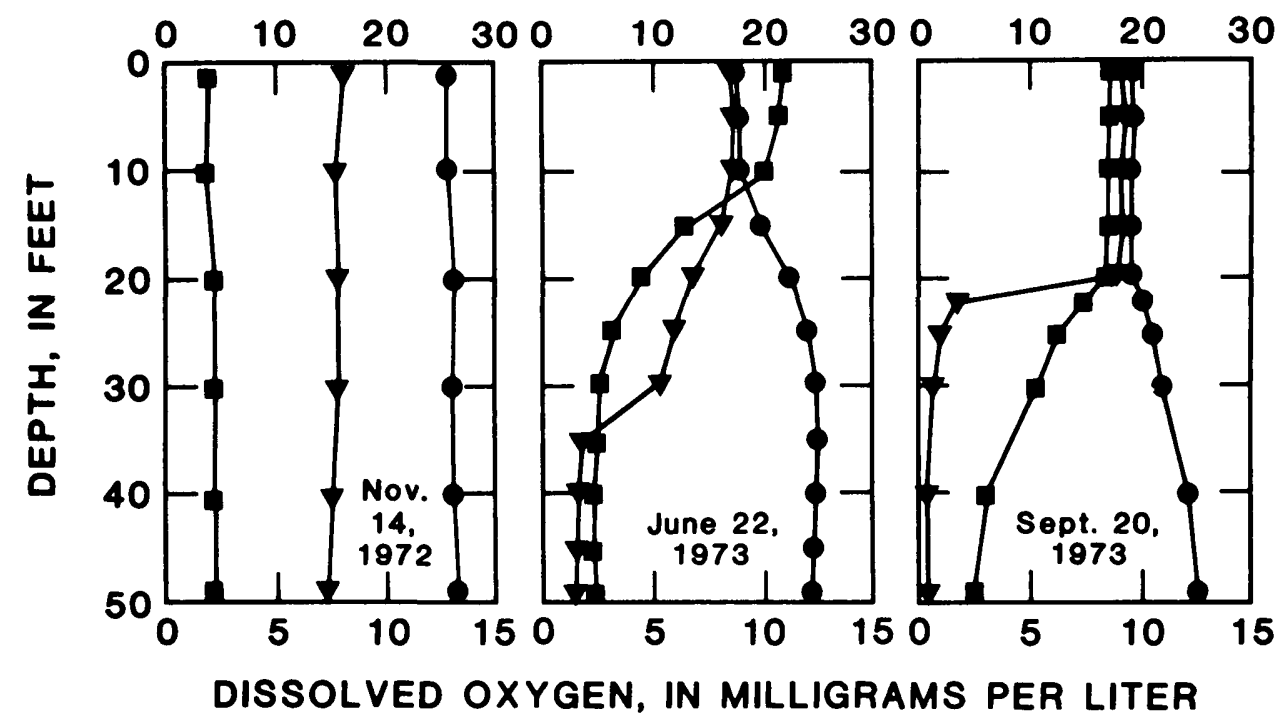

TEMPERATURE, IN DEGREES CELSIUS

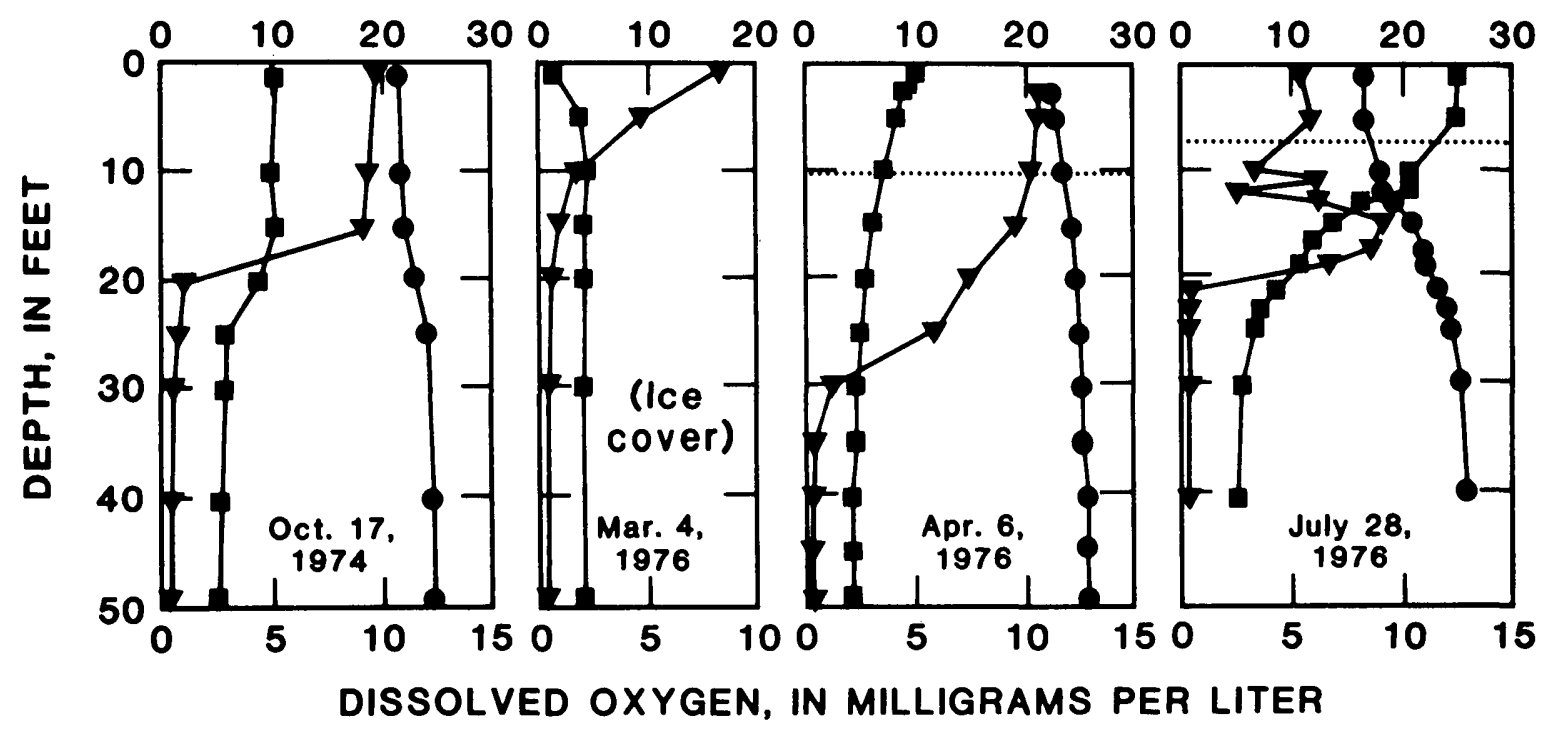

Figure 5.--Temperature and dissolved 


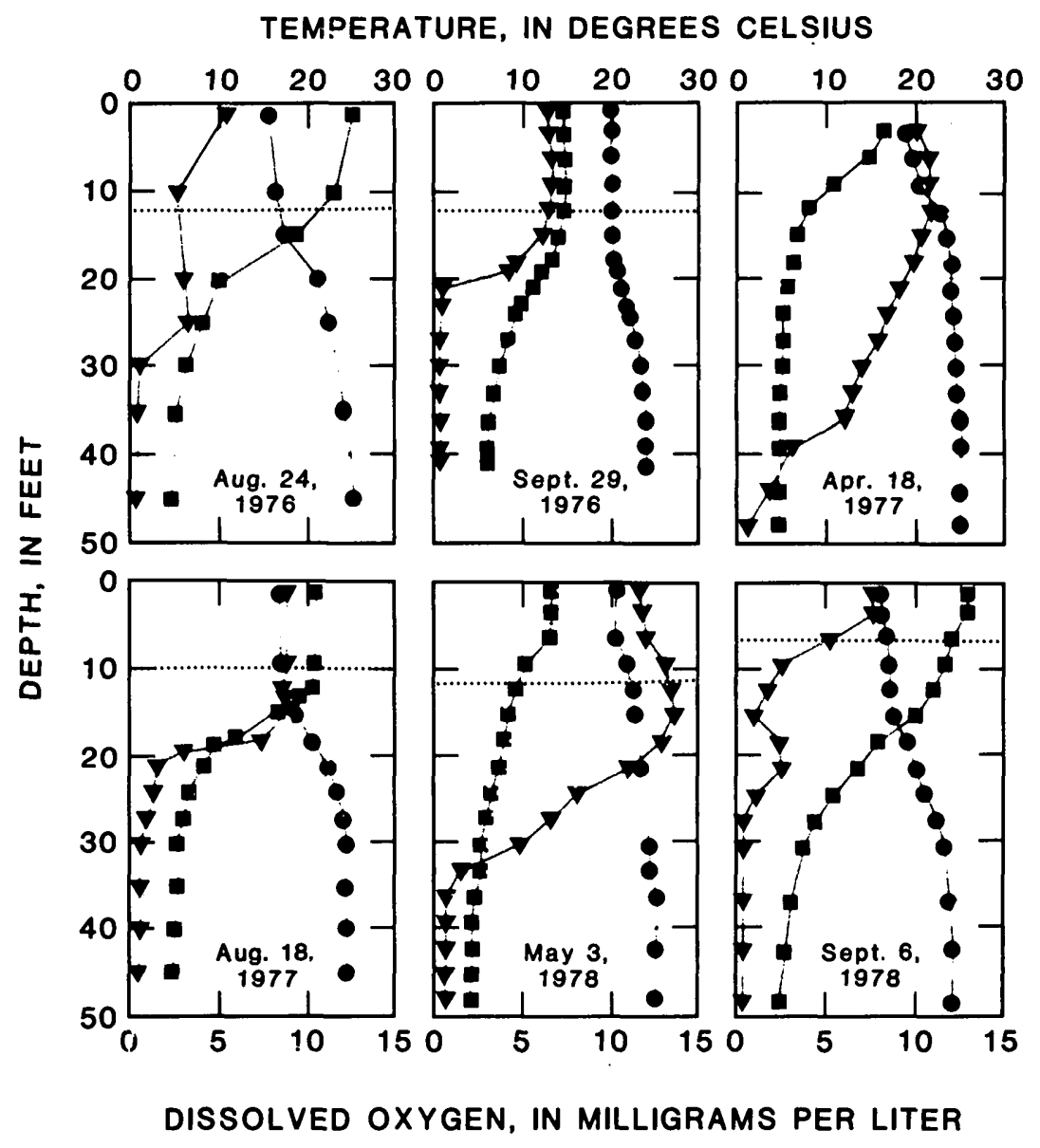

EXPLANATION

- Temperature

$\checkmark$ Dissolved oxygen

- Saturated dissolved oxygen

... Secchi depth

oxygen profiles for Holland Lake 
Table 4.--General water-quality trends $[B G=$ blue-green algae $; D=$ diatoms $; E=$ euglenoid

\begin{tabular}{|c|c|c|c|c|c|c|c|c|}
\hline & \multicolumn{2}{|c|}{ Storm sewer } & \multicolumn{2}{|c|}{ Dissolved oxygen } & \multicolumn{2}{|c|}{ Transparency } & \multicolumn{2}{|c|}{ Chloride } \\
\hline & $\begin{array}{l}\text { In- } \\
\text { let }\end{array}$ & $\begin{array}{l}\text { out- } \\
\text { let }\end{array}$ & $\begin{array}{l}\text { Feb-Mar } \\
1976 \text { 1ce } \\
\text { cover } \\
(\mathrm{mg} / \mathrm{L}) \\
\end{array}$ & $\begin{array}{l}\text { Other } \\
\text { samples } \\
\text { less than } \\
5 \mathrm{mg} / \mathrm{L}\end{array}$ & $\begin{array}{l}\text { Con- } \\
\text { trol } \\
\text { factor }\end{array}$ & $\begin{array}{c}\text { Spring } \\
\text { to } \\
\text { summer } \\
\text { decrease } \\
\end{array}$ & $\begin{array}{l}\text { Spring } \\
\text { to } \\
\text { summer }\end{array}$ & $\begin{array}{l}\text { Variation } \\
\text { during } \\
\text { study }\end{array}$ \\
\hline Blackhawk & -- & 一 & 0.2 & $6-75$ & $\begin{array}{l}\text { Usually } \\
\text { depth }\end{array}$ & - & -- & $\begin{array}{c}\text { Little, } \\
\text { more 1976-77 }\end{array}$ \\
\hline Boesel & -- & - & 0.7 & $9-77$ & Algae & $\mathrm{X}$ & -- & Little \\
\hline Burview Park & $\mathrm{x}$ & - & 11.1 & - & do & $\mathrm{X}$ & - & do \\
\hline Cedar Grove & $\mathrm{X}$ & $\mathrm{X}$ & 11.3 & - & do & $\mathrm{X}$ & $\begin{array}{l}\text { Great } \\
\text { decrease }\end{array}$ & Great \\
\hline Donaldson's Pond & $\mathrm{X}$ & $\mathrm{X}$ & 0.7 & - & do & $\mathrm{X}$ & do & do \\
\hline Fish & $\mathrm{x}$ & - & 7.5 & $8-78$ & Color & - & - & $\begin{array}{l}\text { Rose to } 1977, \\
\text { lowered since }\end{array}$ \\
\hline Hauser & - & - & 0.6 & $\begin{array}{c}9-73,7-76 \\
8-76\end{array}$ & Depth & - & - & Little \\
\hline Holland & - & - & 8.5 & - & Color & - & - & Rose \\
\hline Jensen & - & - & 1.6 & - & Algae & $\mathrm{X}$ & - & $\begin{array}{c}\text { Little, } \\
\text { more 1976-77 }\end{array}$ \\
\hline Lakes1de Estates & $\mathrm{X}$ & - & 4.4 & - & do & $\mathrm{X}$ & - & do \\
\hline Langhoven & $\mathrm{X}$ & $\mathrm{X}$ & 1.8 & $7-76,8-76$ & Depth & - & $\begin{array}{c}\text { Great } \\
\text { decrease }\end{array}$ & Great \\
\hline Lemay & $\mathrm{X}$ & $\mathrm{X}$ & 5.6 & - & Algae & $\mathrm{X}$ & - & $\begin{array}{l}\text { Rose to } 1977 \text {, } \\
\text { lowered since }\end{array}$ \\
\hline McCarthy & - & - & 0.5 & $7-76,8-76$ & $\begin{array}{l}\text { Usually } \\
\text { depth }\end{array}$ & - & - & $\begin{array}{l}\text { Little, } \\
\text { more 1976-77 }\end{array}$ \\
\hline Shanahan & - & - & 0.7 & - & $\begin{array}{l}\text { Usually } \\
\text { algae }\end{array}$ & $\mathrm{X}$ & - & Little \\
\hline Slater's Acres & - & - & 0.0 & - & $\begin{array}{l}\text { Usually } \\
\text { depth }\end{array}$ & - & - & $\begin{array}{l}\text { Little, } \\
\text { more 1976-77 }\end{array}$ \\
\hline Thomas & $\mathrm{X}$ & - & 6.2 & - & Algae & $\mathrm{X}$ & - & do \\
\hline Wilderness & $\mathrm{X}$ & - & 6.7 & - & do & $\mathrm{X}$ & - & do \\
\hline
\end{tabular}


for the 17 study lakes in Fagan

algae; $G$ = green algae; $Y B=$ yellow-brown algae $]$

\begin{tabular}{|c|c|c|c|c|c|c|}
\hline \multicolumn{2}{|c|}{ Dissolved solids } & \multicolumn{2}{|c|}{ Total nitrogen } & \multicolumn{2}{|c|}{ Total phosphorus } & \multirow{2}{*}{$\begin{array}{l}\text { Phytoplankton } \\
\text { Dominant } \\
\text { algae during } \\
\text { the study } \\
\end{array}$} \\
\hline $\begin{array}{l}\text { Spring } \\
\text { to } \\
\text { summer }\end{array}$ & $\begin{array}{c}\text { Variation } \\
\text { during } \\
\text { study } \\
\end{array}$ & $\begin{array}{l}\text { Spring } \\
\text { to } \\
\text { summer }\end{array}$ & $\begin{array}{l}\text { Variation } \\
\text { during } \\
\text { study } \\
\end{array}$ & $\begin{array}{c}\text { Spring } \\
\text { to } \\
\text { summer }\end{array}$ & $\begin{array}{c}\text { Variation } \\
\text { during } \\
\text { study } \\
\end{array}$ & \\
\hline- & Great & - & Great & Increase & Moderate & $B G$, some $G$ \\
\hline- & Little & - & do & do & Moderate & $\mathrm{BC}$ \\
\hline- & Moderate & - & Moderate & -- & Little & $B G$ \\
\hline Decrease & Great & - & Great & varies & Great $1976-77$ & $B G$ \\
\hline Decrease & do & $\begin{array}{c}\text { May } \\
\text { increase }\end{array}$ & do & $\begin{array}{c}\text { May } \\
\text { Increase }\end{array}$ & do & $B G, F, G$ \\
\hline Decrease & Little & - & Little & $\begin{array}{c}\text { May } \\
\text { increase }\end{array}$ & do & $B G, E, G, Y B$, \\
\hline Increase & Great & -- & Great & -- & Great 1976 & $B G, D, E, G, Y B$, \\
\hline- & Little & - & do & $\begin{array}{c}\text { May } \\
\text { decrease }\end{array}$ & Little & $B G, D, E, C, Y B$ \\
\hline - & Moderate & - & do & - & $\begin{array}{c}\text { Great } 1973 \text {, } \\
1976,1977\end{array}$ & $B G$, some $G$ \\
\hline- & Little & - & do & - & Great & $\mathrm{BG}, \mathrm{E}, \mathrm{G}$ \\
\hline- & Great & - & do & - & do & $B G, D, E, G$ \\
\hline- & Moderate & -- & Little & $\begin{array}{c}\text { May } \\
\text { increase }\end{array}$ & do & $B G$ \\
\hline-- & $\begin{array}{l}\text { Little, } \\
\text { more 1976-77 }\end{array}$ & - & do & Increase & $\begin{array}{l}\text { Little, } \\
\text { more 1976-77 }\end{array}$ & $\mathrm{BG}, \mathrm{E}, \mathrm{G}$ \\
\hline- & Little & - & Great & -- & Little & $B G, D, G$ \\
\hline- & Moderate & - & Moderate & - & Great & $B G, D, E, G, Y B$ \\
\hline- & Little & - & do & - & Moderate & $B G$ \\
\hline-- & Moderate & - & Great & Increase & Great & $B G$ \\
\hline
\end{tabular}




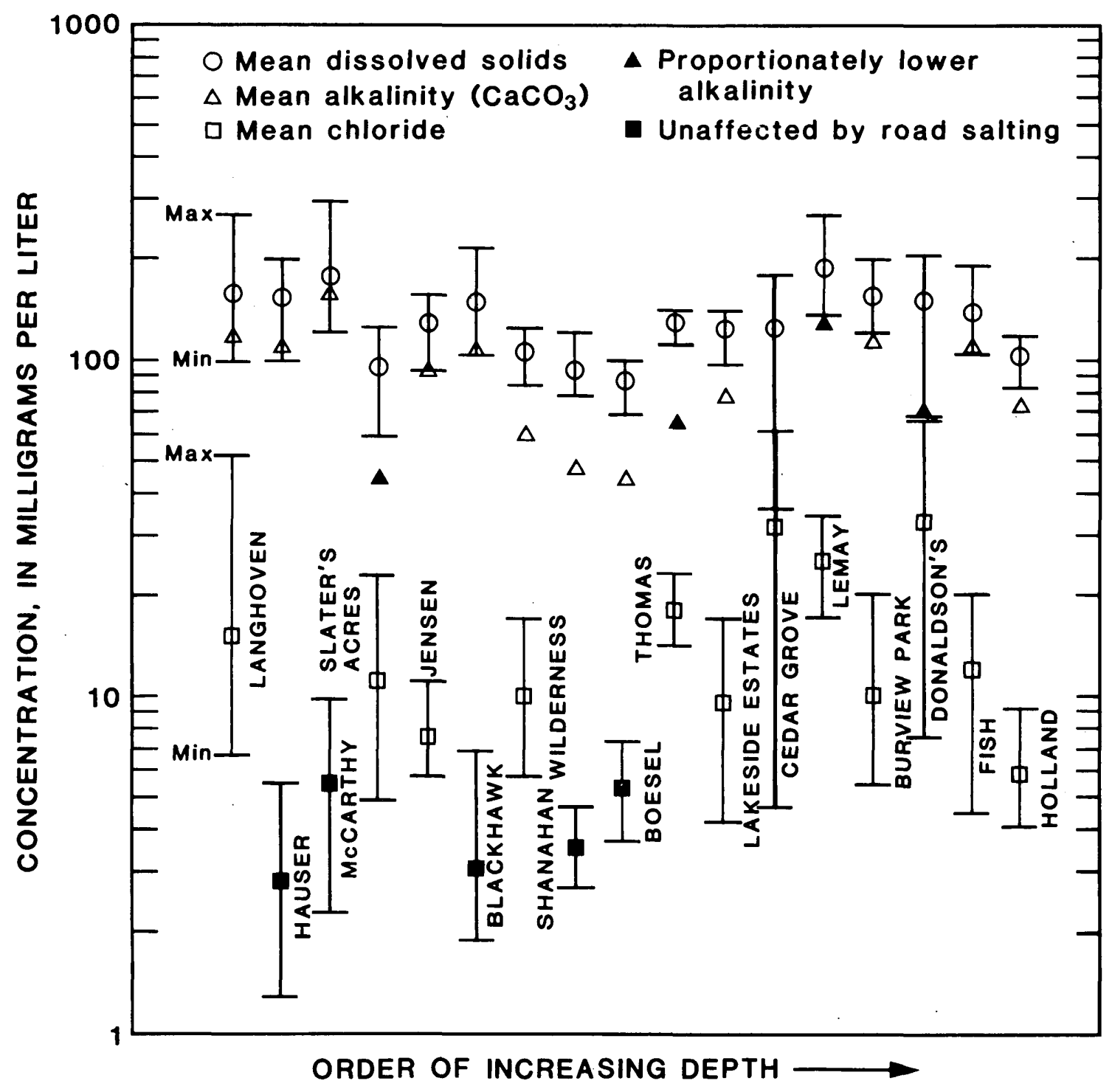

Figure 6.--Mean and range of dissolved solids and chloride and mean alkalinity for study lakes 
having chloride concentrations in excess of $6 \mathrm{mg} / \mathrm{L}$ (fig. 6) show the effects of winter road salting. Hauser, Blackhawk, Shanahan, McCarthy, and Boesel are not significantly affected by delcing salts owing to an absence of roads within their watersheds.

Seasonal variations in chloride (high in spring, lower in fall) were observed only in the lakes with highly urbanized drainages and with outlets (Cedar Grove, Donaldson's, and Langhoven, fig. 6 and table 4). Year to year variations in chloride were quite large in these lakes.

Chloride concentrations were very consistent in Boesel, Burview Park, Hauser, and Shanahan throughout the study period (fig. 6 and table 4). Seven other lakes (Blackhawk, Jensen, Lakeside Estates, McCarthy, Slater's Acres, Thomas, and Wilderness) had consistent chloride concentrations during 1972 through 1975, but increases in chloride from 1.5 to 3 times were observed during the 1976-77 drought. Concentrations have since declined. Fish and Lemay showed more of a steady increase (almost double) in chloride through 1977 and have since declined. Chloride in Holland Lake has steadily doubled from 1972 through 1978.

Trends in chloride are undoubtedly related to urbanization (road salting and munoff), as well as to lake volume and flushing relationships of Individual lakes. Shallow lakes with outlets and highly urbanized drainages were most affected, and the deeper or undeveloped lakes were least affected by chloride inputs.

Seasonal trends in dissolved-solids concentration were observed in only four lakes (table 4). Dissolved sollds in Cedar Grove and Donaldson's Pond decreased from spring to fall primarily because spring inputs of road salts were subsequently flushed by more dilute summer-storm runoff. Fish Lake also shows a decrease in dissolved solids from spring to fall, but the dilution is probably more related to thermal stratification and biologic activity in the epilimion than to input and flushing characteristics. Hauser Pond actually shows an increase in dissolved solids from spring to fall, perhaps owing to the influence of ground-water flux or evaporation on this shallow pond.

Although some seasonal trends were observed, no distinct long-term trends toward increasing or decreasing dissolved-solids concentrations were observed during the study. Rather, the amount of variation observed in each lake was related to land use and to lake volume and depth. Shallow lakes with outlets and highly urbanized drainages had the most variation in dissolved sollds and the deeper or undeveloped lakes had the least.

Figure 7 illustrates the relationship of chloride to dissolved solids for discrete samples in six selected lakes. As mentioned, Donaldson's, Cedar Grove, and Langhoven Ponds all have relatively high concentrations of chloride during spring and early summer, but near background concentrations during summer and fall because of flushing by summer rains. 


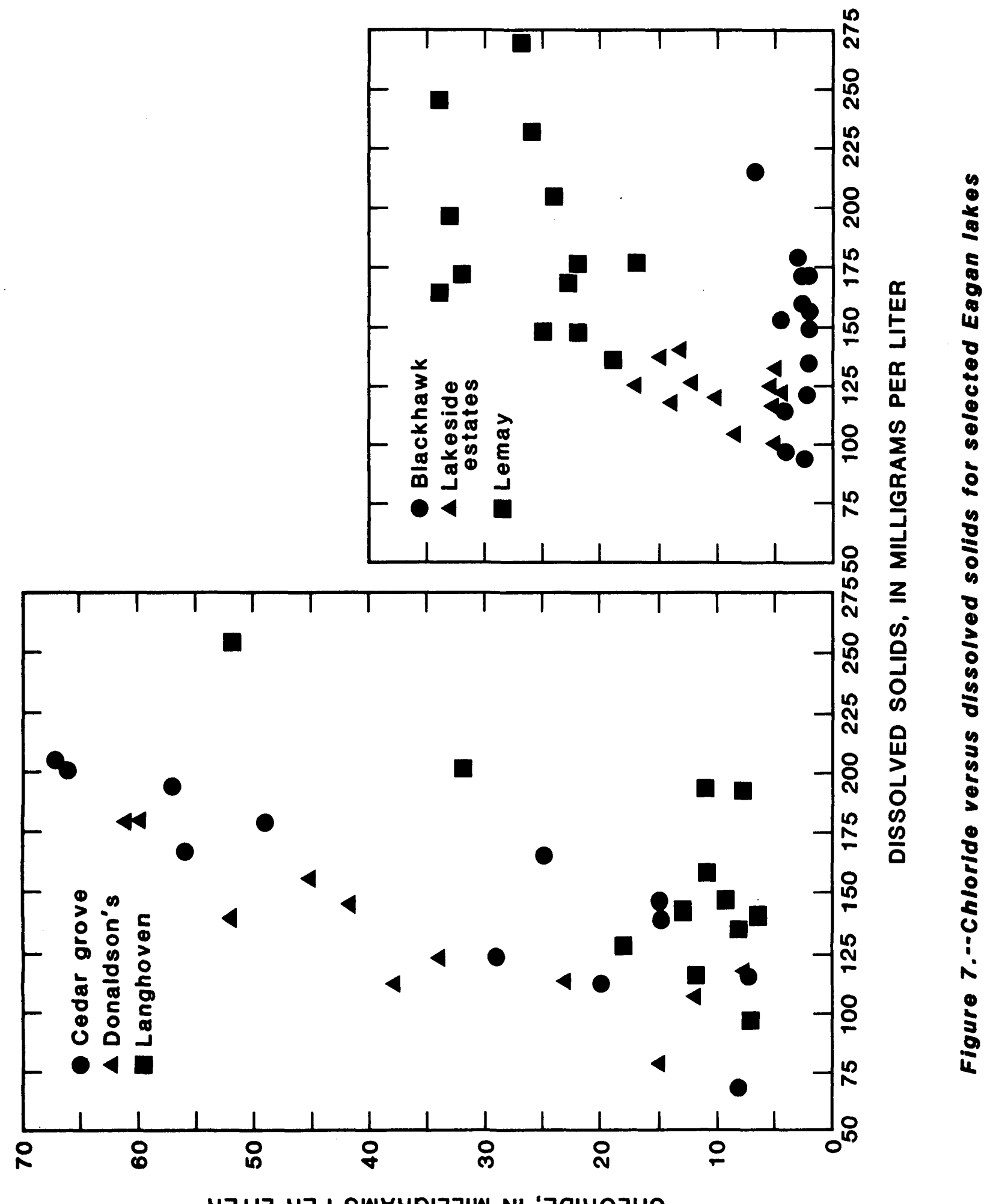

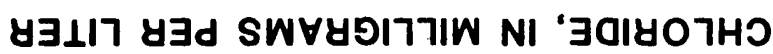


Lemay Lake, which also has a storm-sewer inlet and outlet, flushes less frequently because it is larger and recelves proportionately less urban runoff. Seasonal chloride variations were not found in Lemay Lake; instead, chloride concentrations steadily increased through 1977 and have declined some since.

Lakeside Estates Lake also receives proportionately less urban munoff, but has no outlet. Both chloride and dissolved-solids concentrations in this lake are more stable, and seasonal differences are more subtle owing to the slower flushing rates.

Blackhawk Lake is land locked and does not recelve a slgnificant amount of runoff containing road salts. Chloride concentrations were very low and stable. However, dissolved solids vary considerably in Blackhawk Lake, probably in response to changes in surface runoff, biologic activity, and perhaps to ground-water inflow and outflow.

The variability of dissolved solids, alkalinity, and chloride concentrations for individual lakes is a function of (1) depth (more variability in shallower lakes), (2) the amount of developed area in the watershed (more variability with more percent development), and (3) flushing (more variability in lakes with outlets). Certain lakes without outlets showed an increase in chloride during the study, likely caused in part by urbanization, but intensified by the drought of 1976-77. Thus, even in the absence of urbanization, lakes can undergo significant changes in concentrations of cormon inorganic constituents as a result of extremes in climate.

\section{Nutrients}

Complex interaction of many factors makes it difficult to determine clear cause-effect relationships that account for observed variations in mutrient levels between lakes. The interacting factors include lake depth and volume, presence of inlets and outlets, amount and type of nutrient loading, and combinations of aquatic floral and faunal populations. All these factors interplay in varying degrees to effect changes in loading, flushing, settling, and recycling of nutrients in the Eagan lakes.

The mean value and range of total nutrient concentrations (phosphorus, nitrogen, and organic carbon) for each lake are illustrated in figure 8. The lowest nutrient levels are associated with the deepest lakes, Holland and Flsh. These two lakes have large volumes relative to most other study lakes and, more importantly, these lakes limit continuous recycling of nutrients from bottom materials to surface waters by thermal stratification and entrapment of nutrients in the hypolimion. Thus, Holland and Fish Lakes naturally retain less nutrients in eplilimotic waters than the other lakes studied. Also, neither of the lakes has recelved much urban munoff.

Mean total N (total nitrogen) and TOC (total organic carbon) for all the lakes did not correlate with any morphologic or land-use characteristic. 


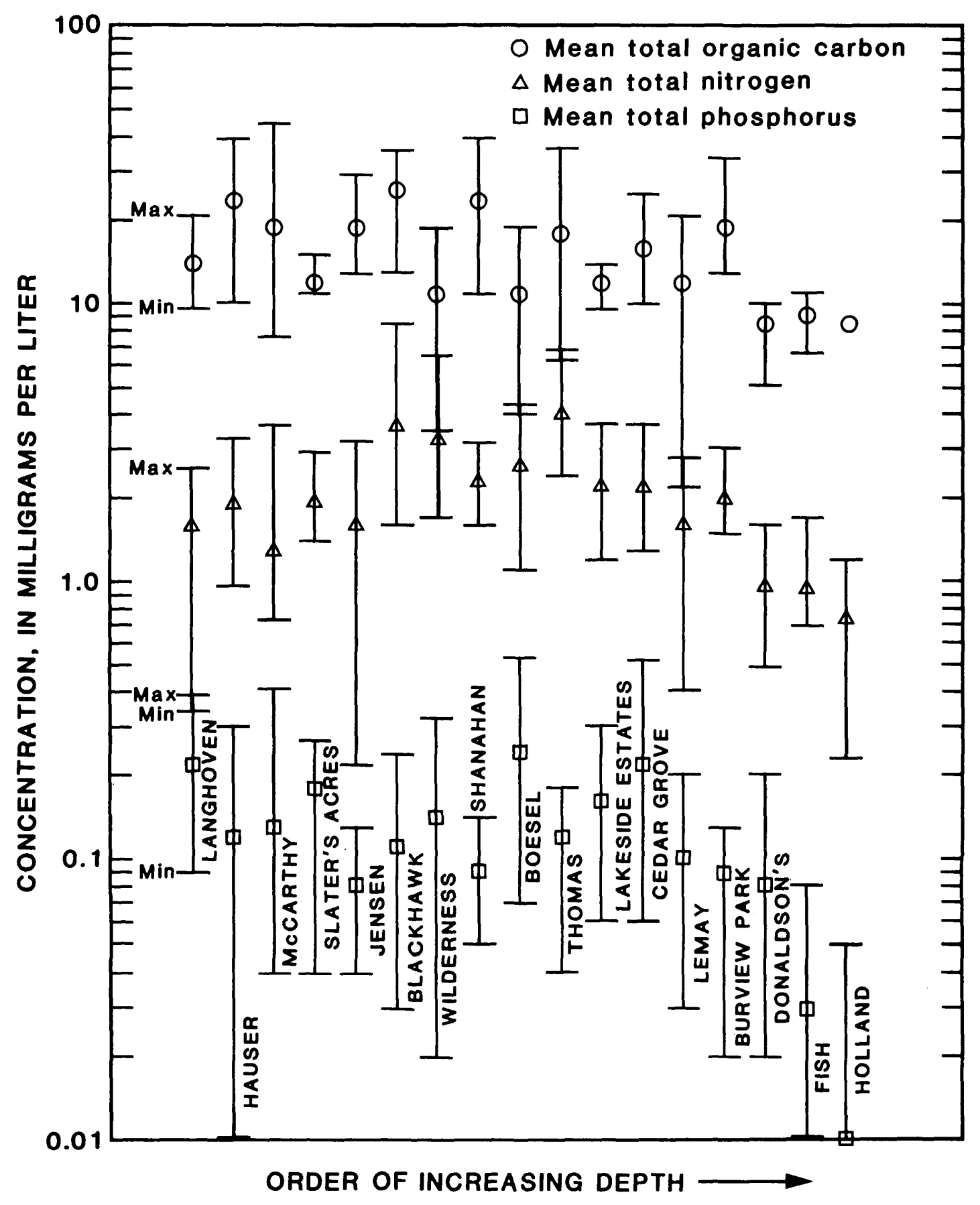

Figure 8.--Mean and range of total organic carbon, nitrogen, and phosphorus for study lakes 
However, total $\mathrm{N}$ was correlated with mean phytoplankton cell count ( $\mathrm{r}=$ 0.69 ). The implication is that total $\mathrm{N}$ concentrations are in part controlled by the abundance of algae. About 80 percent of the total $\mathrm{N}$ is in the organic form, and blue-green algae, some of which have the ability to fix dissolved nitrogen into cellular nitrogen, dominate the lakes. Hence, more total $\mathrm{N}$ was observed with the higher cell counts. Furthermore, concentrations differed considerably between lakes, and no seasonal trends were observed for total N. Only Fish, Lemay, and McCarthy were observed to have any consistency in total $\mathrm{N}$ concentrations from year to year.

The mean ratios of carbon to nitrogen (TOC:TN) for the study lakes ranged from 3.3:1 to 14.6:1. The mean ratio for each lake generally decreases with increasing mean phytoplankton cell count primarily because of the relative increase in nitrogen over carbon with more productivity, again reflecting the interrelationship of blue-green algae and the nitrogen cycle in these lakes. Similar TOC:TN ratios (6.3:1 to 19.4:1) were found in bottom-material samples from the 17 lakes. Data indicate that most of the $\mathbb{T N}$ is in the organic form, thus, the range in ratios suggests that an autochthonous source of bottom materials and organic carbon dominates (Wetzel, 1975, p. 542).

Ratios of nitrogen to phosphorus (TN:TP) ranged from 7.3:1 to 73:1. The ratios correlated with lake volume $(r=0.89)$, mean or maximum depth $(r=0.84$ each $)$, and transparency $(r=0.75)$. However, the correlations are biased by the low phosphorus levels in the larger, deeper lakes. Nitrogen to phosphorus ratios $(5.4: 1$ to $96: 1$ ) for bottom-material samples did not correlate with $\mathbb{T N}$ : TP in water samples, but correlated weakly with lake area $(r=0.66)$.

TN:TP ratios inversely correlated with TP $(r=-0.69)$, which, according to Sakamoto (1966), suggests an increasing probability of nitrogen, rather than phosphorus, limitation in lakes where the ratio is less than 13:1. The ratio was 13:1 or less in Boesel, Cedar Grove, Donaldson's, Langhoven, McCarthy, and Slater's Acres.

Total-phosphorus concentrations increased from spring to surmer only in Blackhawk, Boesel, Donaldson's, Lemay, McCarthy, and Wilderness Lakes (table 4), most likely from internal recycling. It is uncertain why similar increases were not observed in the other shallow lakes. Conversely, totalphosphorus concentrations in Holland and Fish were observed to decrease through the summer, likely from a loss of phosphorus by settling of algal cells out of the epilimnion.

Although seasonal trends were observed for some lakes, long-term trends were not observed. Total-phosphorus concentrations varied considerably in Lakeside Estates, Langhoven, Lemay, Slater's Acres, Thomas, and Wilderness Lakes without any obvious long-term trends (table 4). Whereas, Blackhawk, Burview Park, Holland, and Shanahan Lakes had relatively consistent phosphorus concentrations hroughout the study. Fairly consistent phosphorus 
concentrations were also found in Boesel, Cedar Grove, Donaldson's, Fish, Hauser, Jensen, and McCarthy, except that higher concentrations were observed during the 1976-77 drought. Except for Boesel, these drought-affected lakes seemed to recover by 1978 .

Mean total-phosphorus concentrations in each lake were weakly correlated with lake volume $(r=-0.66)$, maximum depth $(r=-0.63)$, estimated flushing rate per year $(r=0.54)$, estimated load of phosphorus entering the lake per year $(r=0.53)$, and percentage of drainage developed $(r=0.53)$. However, these correlations are biased by the inclusion of the deeper Holland and Fish Lakes in the data set. Boesel Pond is physically similar to the shallower Eagan lakes but has high total-phosphorus concentrations, probably resulting from runoff from a barnyard and pasture.

Phosphorus Regression Model

Exclusion of Holland, Fish, and Boesel from the correlation analysis resulted in a shift in important factors. Total phosphorus correlated more with urban loading factors such as percentage of drainage area developed $(r=0.80)$ and estimated phosphorus load $(r=0.74)$, but less with morphologic characteristics such as lake volume $(r=-0.51)$ and maximum depth $(r=-0.39)$. Many different transformations of the above variables were tested to determine the most significant correlation with total phosphorus. Stepwise, multiple regression resulted in the following model for total phosphorus:

$$
\mathrm{TP}=(3635381+92297 \mathrm{DEVP}-590429 \mathrm{LOGVOL})^{1 / 3}
$$

where: $\mathrm{TP}=$ total phosphorus in micrograms per liter,

$\mathrm{DEVP}=$ percentage of drainage area developed,

LOGVOL = natural $\mathrm{log}$ of lake volume in acre-feet.

The model correlation coefficient is $0.93\left(r^{2}=0.87\right)$, and the model standard error or coefficient of variation is +42 percent. However, 11 of the 14 predicted values were within 20 percent of the observed total phosphorus. The three lakes not fitting the regression model also had three of the lowest measured total-phosphorus values; these were Donaldson's (68 percent high), Burview (39 percent high), and Shanahan (26 percent high). The high predicted values for Donaldson's and Burview may result from overestimation of the developed area contributing to these lakes or to a lower yield of phosphorus per unit of developed area in the lake drainages.

The regression model is applicable for predicting total phosphorus concentrations in shallow (less than 10 or 12 feet maximum depth), nonstratifying lakes and ponds in the Fagan area--provided that they receive 
munoff typical of the areas studied. A case in point is Boesel Pond, which receives atypical loadings of phosphorus in runoff from barnyards and pastures. In this case, the model severely underestimates the total phosphorus concentration. Furthermore, the methods for computing drainage areas, developed areas, and lake volumes would have to be consistent with the methods used in this analysis."

Considering these constraints, the regression model can be useful in predicting total phosphorus concentrations in Eagan lakes and ponds under increasing urbanization. In turn, the predicted concentrations can be related to changes in lake quality, such as transparency or chlorophyll a. For example, figure 9 illustrates the predicted changes in total phosphorus concentration for different lake volumes. The family of curves converge as the percentage development increases, indicating that, for a given lake area, the role of lake depth is considerably more important in the early stages of urban development than in the more advanced stages.

\section{Phosphorus Parametric Models}

For comparison, several phosphorus-prediction models of the parametric type were tested. (See Dillon and Rigler, 1975; Chapra and Tarapchak, 1976; Jones and Bachmann, 1976; Reckhow, 1977; Walker, 1977; - all summarized in Reckhow, 1979). Methods for calculating the input data to these models are given in the Methods and Approach section. Most of the Eagan lakes are shallow closed basins, and thus, do not meet some basic assumptions of the parametric models. Therefore, reliable predictions of phosphorus concentration through the use of these models was not anticipated. The results of predictions through the use of the published models ( 5 through 10, table 5) did not agree well with observed concentrations. Factors that might account for the observed differences include (1) recycling of phosphorus from bottom sediments owing to the shallow, nonstratifying nature of the lakes, (2) effects of littoral aquatic vegetation on phosphorus uptake and settling, (3) winterkill of planktivorous fish, resulting in increased grazing of algae by zooplankton, which affects cycling and settling of phosphorus, and (4) flux of ground water through the lake systems.

Figure 10 illustrates the results of the two parametric models (Jones and Bachman, 1976; Reckhow, 1977) that best fit the Eagan data. Predictions of total phosphoms concentrations in lakes that stratify, Holland and Fish, are consistently overestimated by 200 to 300 percent, as are predictions for shallow lakes with outlets that flush two or more times per year (Donaldson's, Cedar Grove, and Langhoven). Similar results were found through the use of other models, which implies that stratification and flushing are important in controlling increased phosphorus concentrations in the Eagan lakes. However, although flushing seems to be beneficial locally, the downstream effects of flushed-out phosphorus may not be beneficial. 


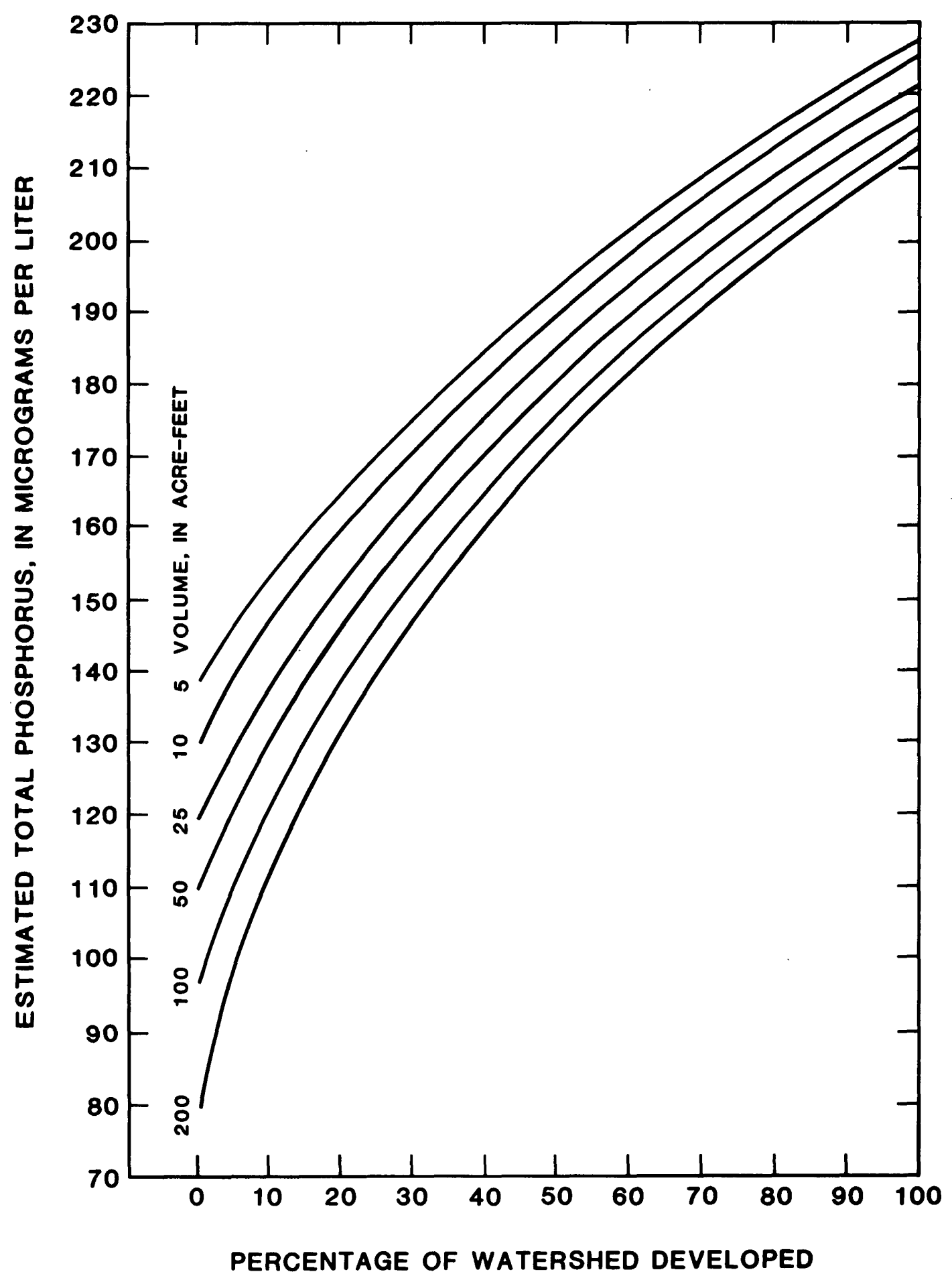

Figure 9.--Estimated total phosphorus as a function of percentage of watershed developed and lake volume for shallow, nonstratifying lakes in Eagan 

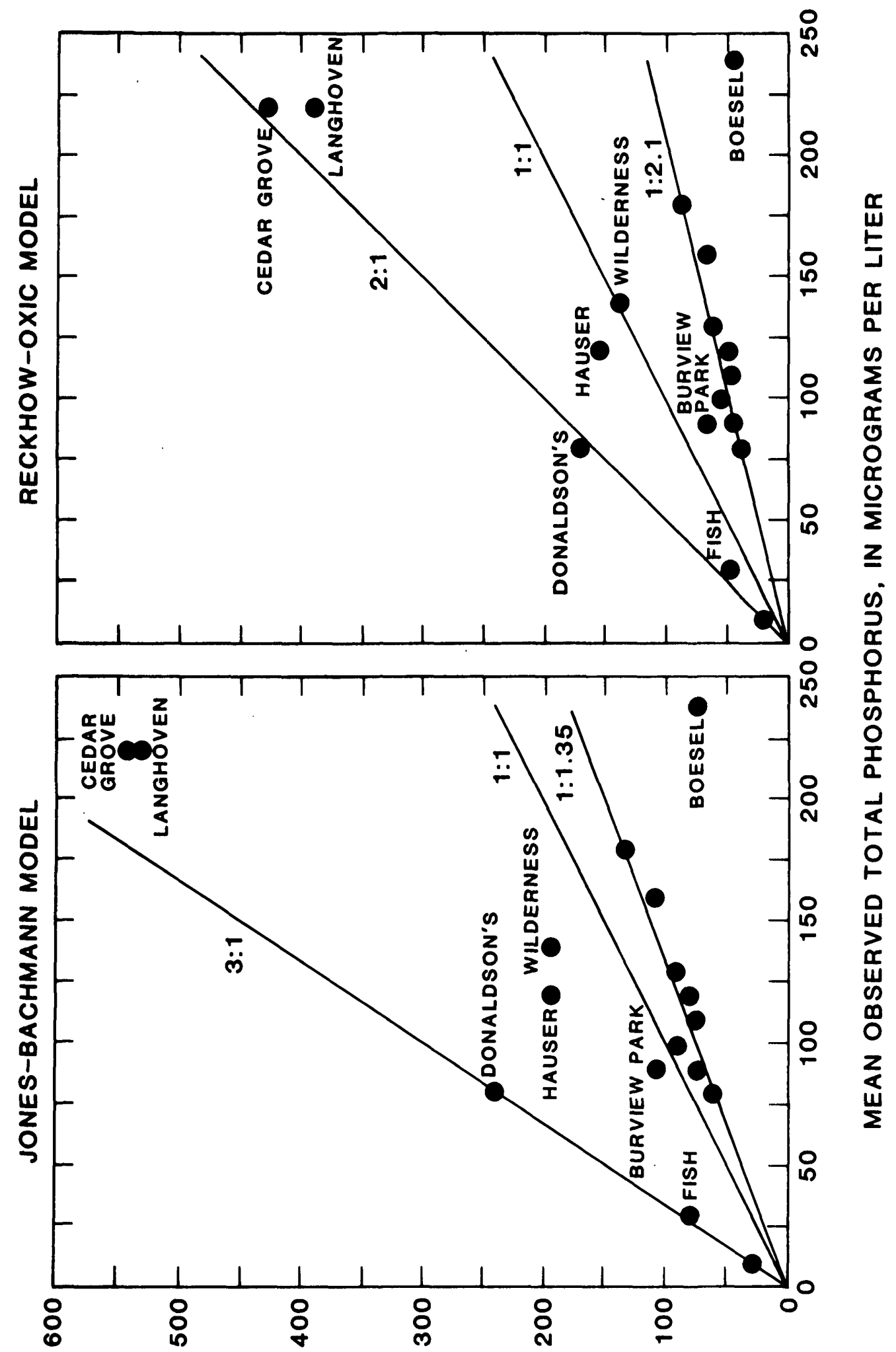

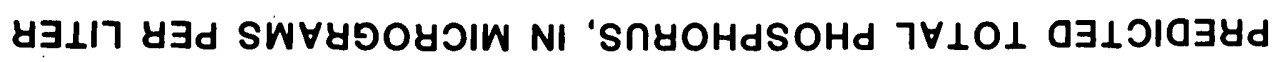

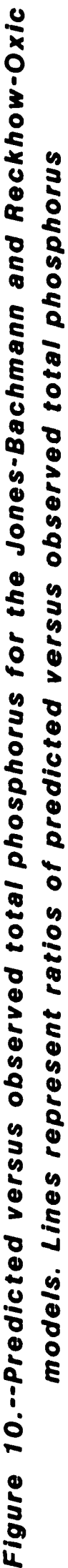




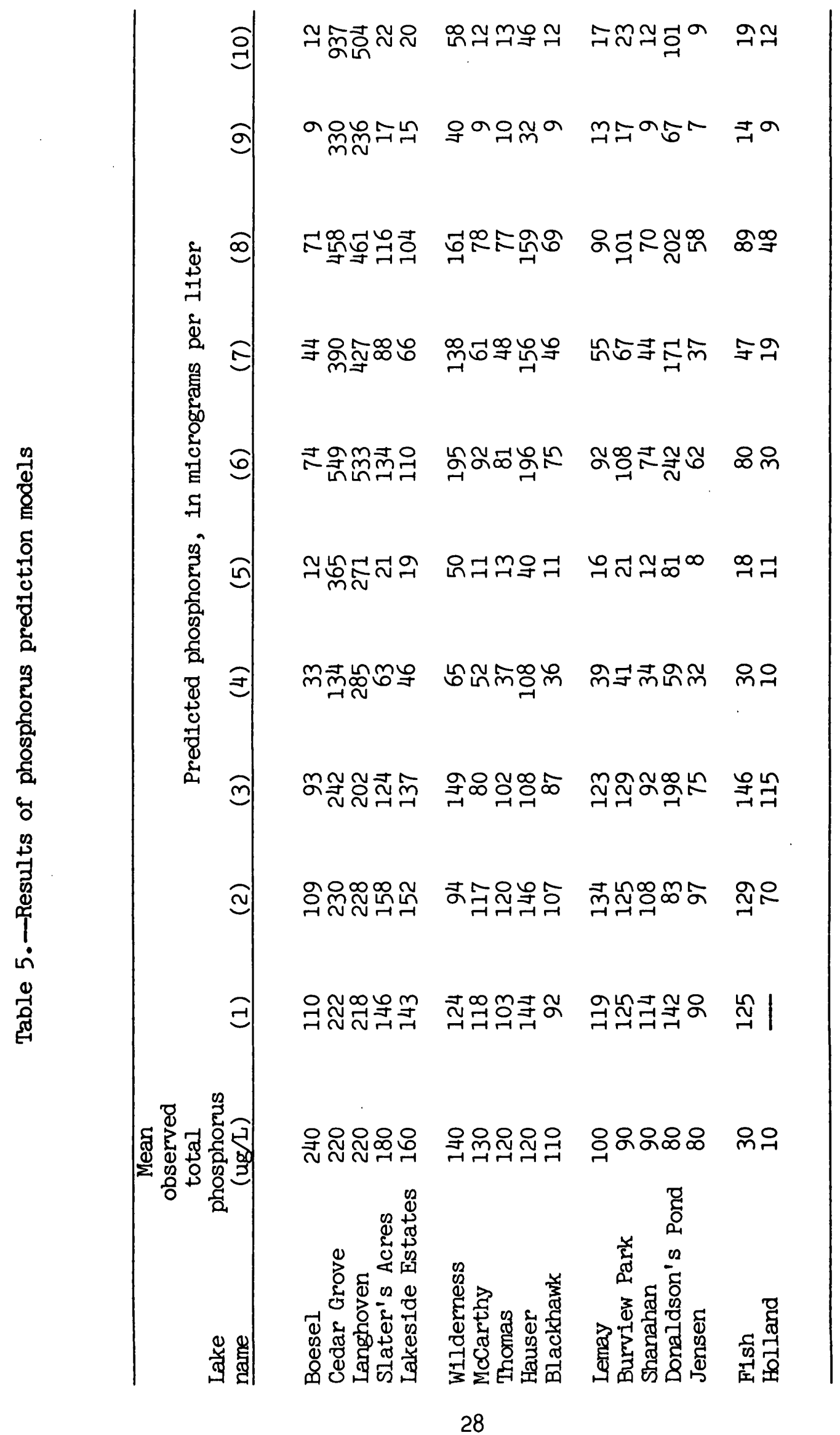




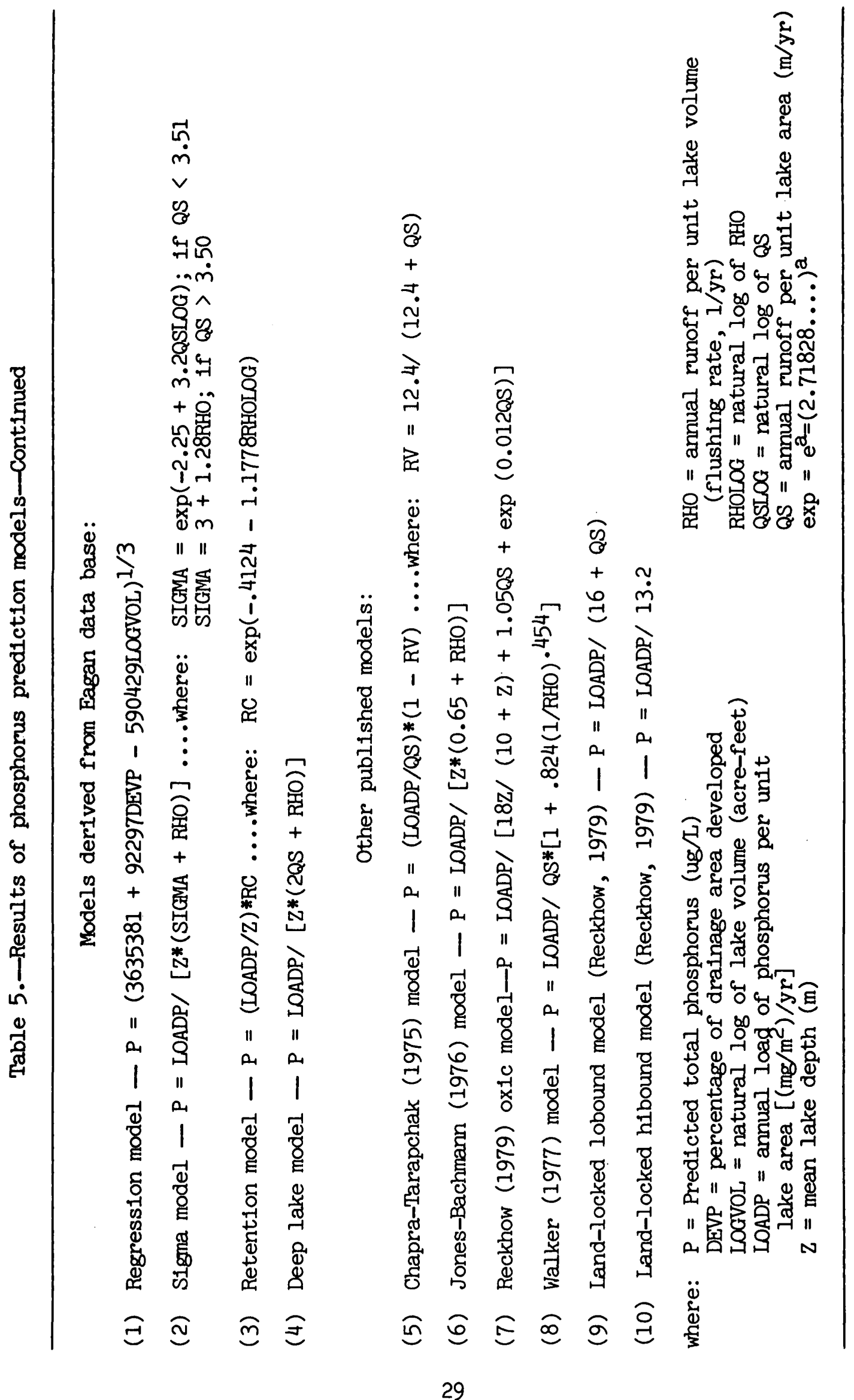


Phosphorus concentrations in shallow lakes that flush about once per year are underestimated by about 35 percent in the Jones-Bachmann model and by 110 percent in Reckhow's model. The underestimation for this group of lakes is probably the result of recycling of phosphorus from bottom material. The other parametric models underestimated total phosphorus for this group of lakes to an even greater extent.

Lack of confidence in the parametric models for predicting phosphorus concentrations led the authors to derive similar formulations with coefficlents better suited to the Eagan lakes. Results of the two best formulations are presented in table 5 (models 2 and 3). The Eagan sigma model (model 2) uses a formulation similar to Jones and Bachmann (model 6) with a variable instead of a constant settling coefficient (SIGMA). The rationale was to determine empirically a net settling coefficient that accounted for the combined effect of settling and bottom recycling of phosphorus and was dependent upon depth or flushing (QS or RHO, table 5). The sigma model predicted concentrations in 10 of the 14 shallow lakes within 20 percent of the observed total phosphorus concentrations.

A retention model (table 5, model 3) of the Eagan lakes utilizes a lumped retention coefficient that includes all the effects of settling, recycling, and flushing to predict the total phosphorus concentration in each lake. Although less arbitrary, the model is also less sensitive than the sigma model. Predicted total phosphorus was within 20 percent of actual values in 8 of the 14 lakes and within 30 percent in 10 of the 14 lakes. This model did not predict the high flushing lakes as well as the sigma model.

The choice of the appropriate predictive model for the deep lakes, Holland and Fish, is difficult because observed values are avallable from only two lakes for testing against predicted values. Total phosphorus in Holland Lake is approximated with the Chapra-Tarapchak and the Reckhow lobound and hibound models (table 5, models 6, 9, and 10). Total phosphorus in Fish Lake is not predicted well by any of the published models. A simple model (Eagan deep lake, table 5), where the settling coefficient (SIGMA) is approximated as two times QS, seems to fit quite well with both Holland and Fish data and with Smith's (1979) data for Heine Pond. This model would need further testing on a larger set of data to establish confidence in its applicability.

\section{Trophic State Delineation}

Efforts to predict the effects of urbanization on the quality of Eagan lakes are linked to the important role of phosphorus in the trophic state of lakes (Reckhow, 1979). Figures 11 and 12 illustrate the interrelationships of total phosphorus, transparency, and chlorophyll a for the Eagan lakes. 


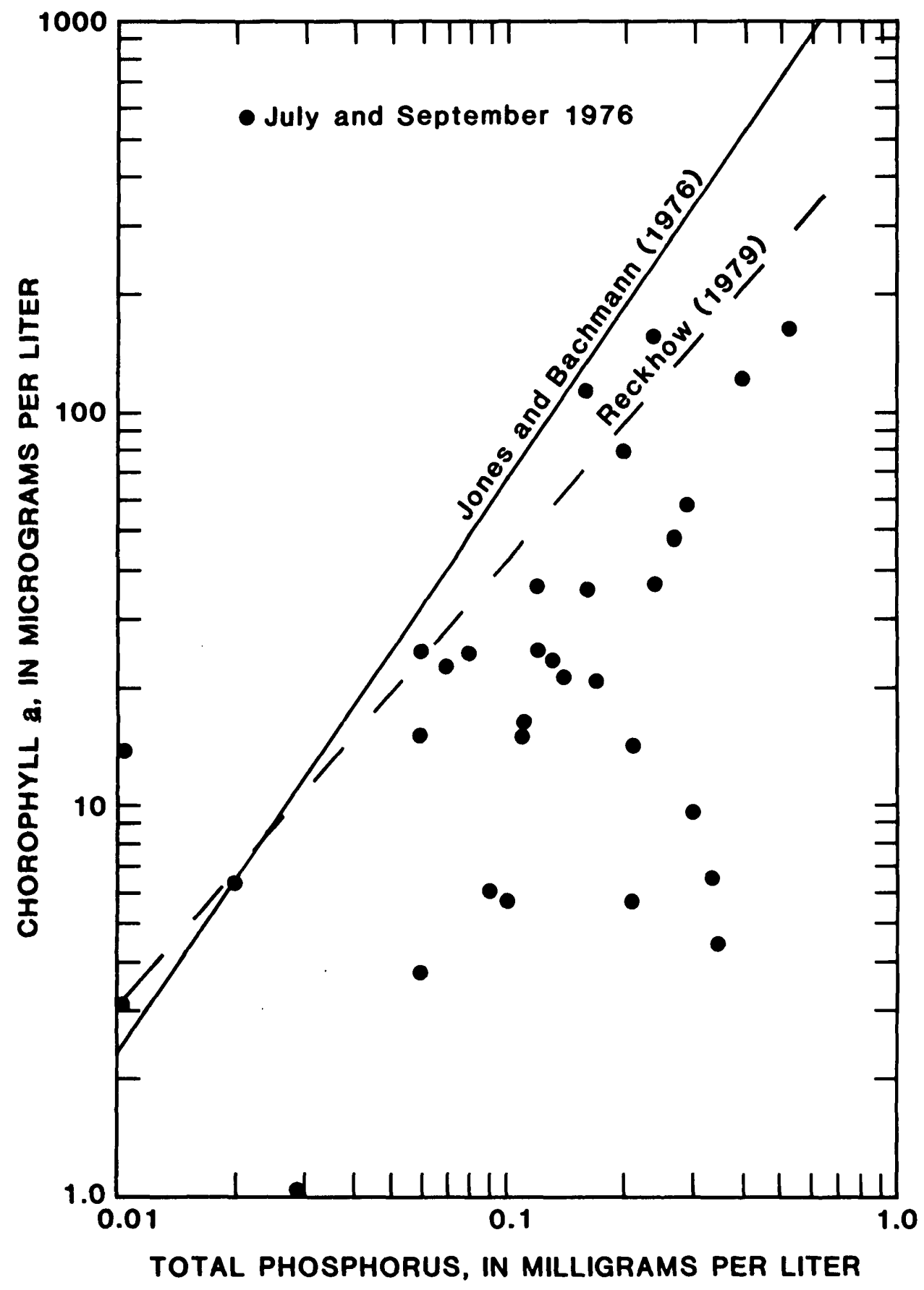

Flgure 11.--Chlorophyll a versus total phosphorus (summer 1976 data) for study lakes 


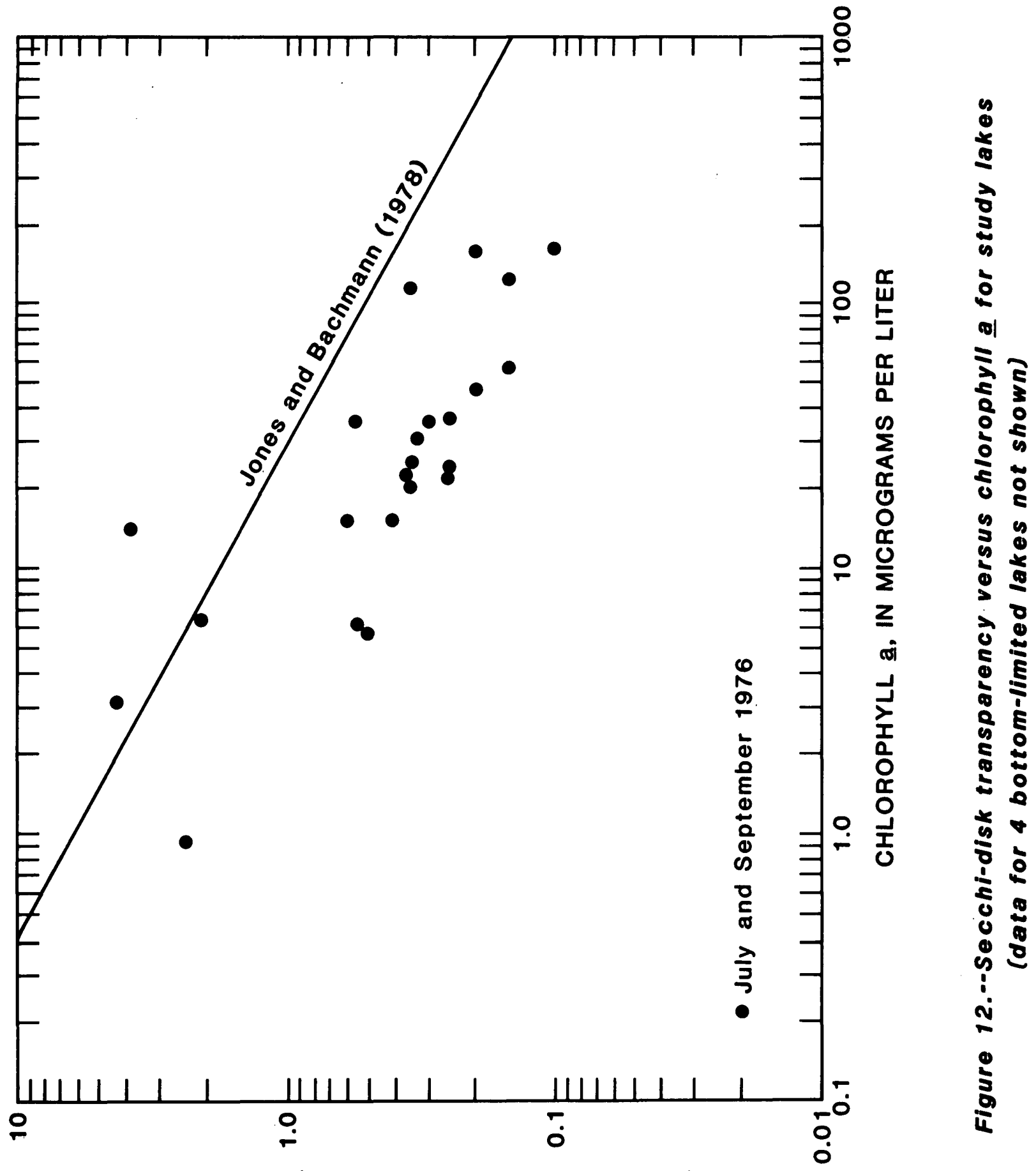

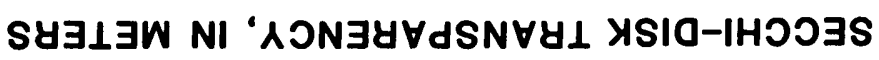


Table 6.--Trophic classification for Eagan lakes

U.S. Environmental Protection Agency (1974)

Trophic State Delineation

\begin{tabular}{llll} 
Lake & Phosphorus & Transparency & Chlorophyli a \\
\hline Holland & mesotrophic & mesotrophic & mesotrophic \\
Fish & eutrophic & mesotrophic & oligotrophic \\
Burview & eutrophic & eutrophic & mesotrophic \\
Hauser & eutrophic & eutrophic & mesotrophic \\
Langhoven & eutrophic & eutrophic & mesotrophic \\
12 others & eutrophic & eutrophic & eutrophic \\
\hline
\end{tabular}

Carlson (1977) Trophic State Index

\begin{tabular}{lcccc} 
Lake & Average & Phosphorus & Transparency & Chlorophyll a \\
\hline Holland & 50 & 40 & 50 & 60 \\
Fish & 53 & 60 & 50 & 50 \\
Burview & 63 & 70 & 70 & 50 \\
Blackhawk & 67 & 80 & $60 *$ & 60 \\
Donaldson's Pond & 67 & 70 & 70 & 60 \\
Shanahan & 67 & 70 & $60 *$ & 70 \\
Jensen & 70 & 70 & 70 & 70 \\
Hauser & 73 & 80 & $80 *$ & 60 \\
Lakeside Estates & 73 & 80 & 70 & 70 \\
Lemay & 73 & 80 & 70 & 70 \\
Slater's Acres & 73 & 80 & $70^{*}$ & 70 \\
Langhoven & 73 & 90 & $80 *$ & 70 \\
McCarthy & 77 & 80 & $80^{*}$ & 80 \\
Thomas & 80 & 80 & 80 & 80 \\
Wilderness & 80 & 80 & 80 & 70 \\
Cedar Grove & 80 & 90 & 80 & 80 \\
Boesel & 80 & 90 & 70 &
\end{tabular}

*Bottom limited secch1. 
A higher total phosphorus generally leads to increased algal production (chlorophyll a) and to reduced transparency. However, even the lakes with undeveloped drainages have phosphorus concentrations that support considerable algal production and cause low transparencies (less than 3 feet). According to Vollenweider's (1976) loading criteria, only Holland Lake is estimated to be receiving a phosphorus load that does not cause an eutrophic condition, but is above the critical loading level for an oligotrophic lake. The rest of the Eagan lakes are well into the eutrophic level of loading. Consequently, most of the lakes in the Eagan area are highly eutrophic (table 6). Carlson's index indicates that Holland and Fish are the least eutrophic lakes, and Thomas, Wildemess, Cedar Grove, and Boesel are the most eutrophic. The use of a predictive tool for most of these lakes, then, is only to determine the relative change within their trophic state. Only deep lakes like Holland, Fish, and Heine (Smith, 1979), which are presently bordering on the mesotrophic-eutrophic states, can undergo marked changes in trophic state or lake quality.

\section{Phytoplankton}

The eutrophic nature of the lakes in Eagan is reflected in the phytoplankton cell counts (fig. 13). Most of the lakes have populations above $500,000 \mathrm{cells} / \mathrm{mL}$, but occasionally have low cell counts as well. These more productive lakes typically are dominated by blue-green algae (primarily Anasystis, Oscillatoria, Anabaena, and Lyngbya, table 7). The high populations are in response to high levels of available nutrients and to other favorable growth conditions. Low counts, on the other hand, are probably due to samples being taken during or just after environmental stress such as urban munoff shock loading, heavy grazing by zooplankton, dieoff of an algal bloom, ice cover, and temporary nutrient deficlency.

Some of the lakes in Eagan have consistently low algal populations in spite of high nutrient concentrations (Hauser, Langhoven, McCarthy, Donaldson's, Slater's Acres and perhaps Shanahan). These lakes are the shallowest lakes studied. Most of these lakes also have dense populations of emergent aquatic vegetation around the shorelines (cattails, arrowhead, and others), which could compete with algae for nutrients. However, competition would have to be eliminated as a major cause for low algal populations because the nutrient levels observed in these lakes are still high enough to support large algal populations. More likely, enviromental conditions are severe enough in most winters to eliminate all fish in these

lakes. The lack of planktivorous fish results in abundant zooplankton populations and, consequently, in heavy grazing of algae (Val Smith, University of Minnesota Limnological Research Center, oral commun., March 1979). In contrast to the more productive lakes, these lakes had mixed dominance by blue-green, green, and euglenoid types of algae (table 7). 


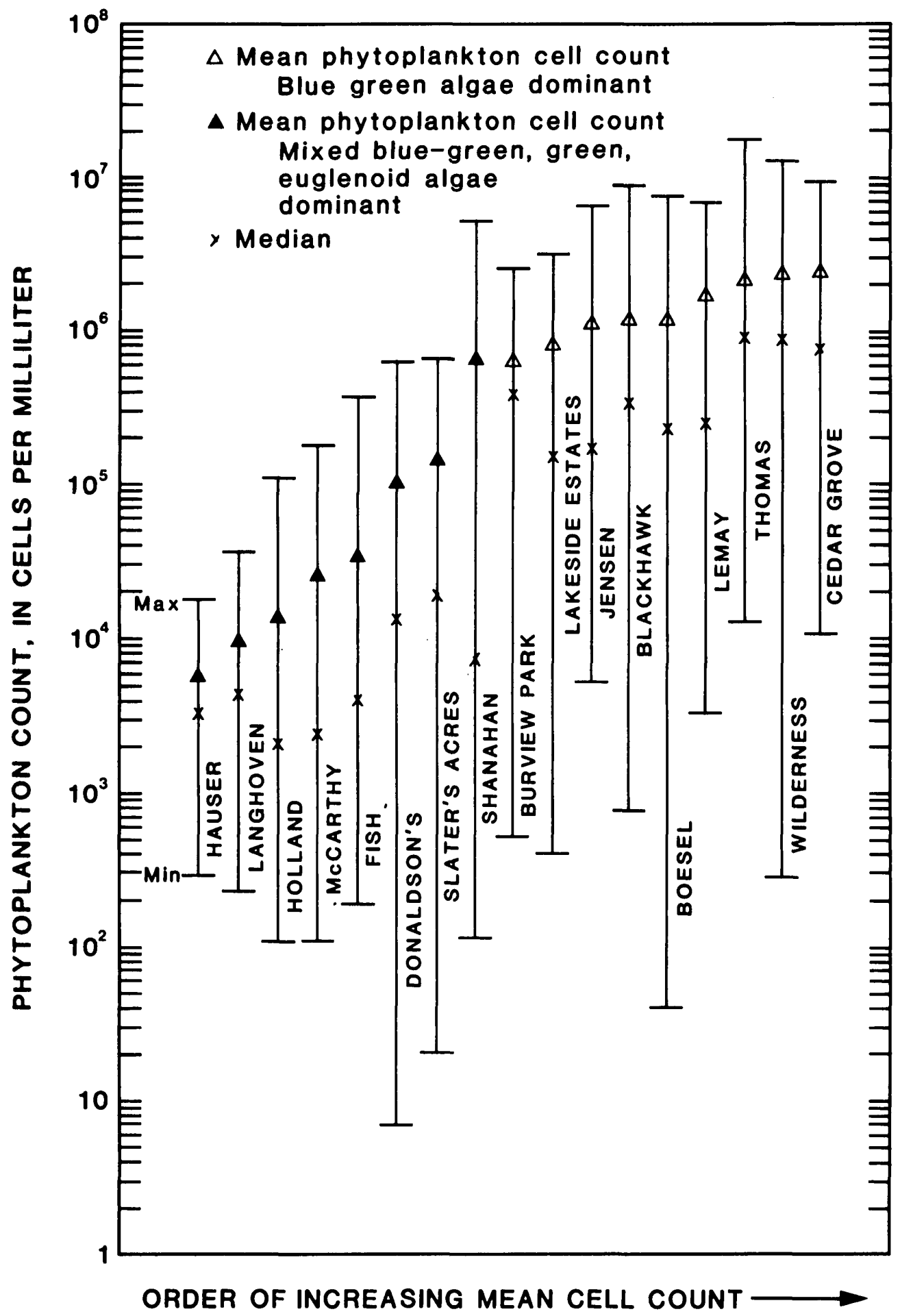

Figure 13.--Mean and range of phytoplankton cell count for study lakes 
Table 7.--Dominant and codominant algal genera in phytoplankton samples of 17 study lakes in Eagan

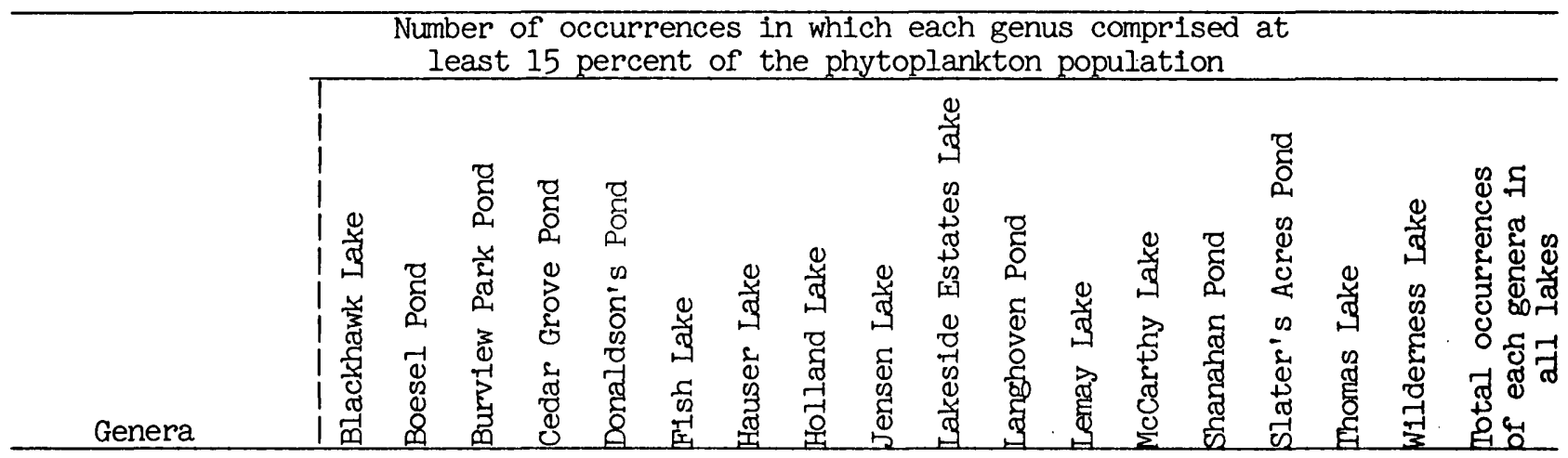

Blue-green algae

\begin{tabular}{|c|c|c|c|c|c|c|c|c|c|c|c|c|c|c|c|c|c|c|}
\hline Agmenel & -0 & - & 2 & 1 & - & - & - & - & - & - & - & 1 & - & - & - & - & - & 4 \\
\hline Agmexel1um & 1 & -- & -- & -- & - & - & -- & -- & -- & - & -- & - & -- & - & - & - & - & \\
\hline Aphanocapsa & 1 & - & - & -- & - & - & - & - & - & - & - & 1 & - & 1 & - & 一 & - & \\
\hline zomeron & 1 & -- & -- & 1 & 1 & - & -- & -- & 1 & 1 & 1 & 1 & - & - & 2 & 1 & 1 & \\
\hline nabaena & 2 & 2 & 1 & 2 & 2 & - & 1 & 1 & - & 2 & - & 1 & 2 & 1 & 2 & 3 & 2 & \\
\hline Inabaenopsis & - & - & - & - & - & - & - & - & - & - & - & - & - & - & 1 & - & - & \\
\hline Anacystis & 5 & 5 & 7 & - & - & 6 & 3 & 7 & 8 & 5 & 1 & 8 & 2 & 1 & 3 & 5 & 3 & \\
\hline ospe & 1 & - & -- & 2 & - & - & -- & - & 2 & 2 & - & 1 & 1 & 1 & - & 3 & 2 & \\
\hline Lococcopsis & -- & - & 1 & - & 1 & - & - & - & - & 1 & - & - & - & - & 一 & - & - & \\
\hline Gomphosphaeria & 1 & -- & 1 & 2 & 1 & 2 & -- & - & 2 & -- & - & 1 & 1 & 2 & 1 & 5 & - & \\
\hline & 3 & 4 & 2 & 4 & 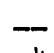 & - & - & 一 & 4 & 1 & 2 & 3 & 1 & 2 & - & - & 2 & \\
\hline ria & 2 & 5 & 7 & 11 & 4 & 1 & ? & 1 & 2 & 4 & 4 & 8 & & 2 & & 7 & 0 & \\
\hline Raphidiopsis & - & - & - & - & - & - & - & - & - & - & - & - & 1 & - & 7 & - & & \\
\hline
\end{tabular}

\begin{tabular}{|c|c|c|c|c|c|c|c|c|c|c|c|c|c|c|c|c|c|}
\hline & & & & & & & & & & & & & & & & & \\
\hline $\mathrm{Coc}$ & - & - & - & - & - & - & - & - & - & - & 1 & - & - & - & - & - & - \\
\hline La & -- & - & - & - & -- & 1 & 1 & - & - & -- & -- & -- & - & - & - & - & - \\
\hline Nitzschia & 1 & - & - & - & - & - & - & - & - & - & - & - & - & - & 1 & - & - \\
\hline sstanoe & -- & -- & - & -- & -- & -- & -- & 1 & - & -- & -- & -- & - & - & - & - & -- \\
\hline
\end{tabular}

Flagellated algae

\begin{tabular}{|c|c|c|c|c|c|c|c|c|c|c|c|c|c|c|c|c|c|}
\hline Ceratium & - & - & - & - & - & - & - & 一 & - & - & - & - & - & 1 & - & - & - \\
\hline Cryptomonas & -- & - & -- & - & - & 2 & 1 & 1 & -- & 1 & 2 & - & - & - & - & - & - \\
\hline Eudorina & - & - & - & -- & - & - & - & - & - & - & 1 & - & - & - & - & - & - \\
\hline Euglena & -- & -- & - & - & - & - & 1 & - & - & - & 2 & -- & - & - & - & - & - \\
\hline Glenodinium & - & - & - & - & - & - & - & - & - & - & 一 & 一 & 1 & 一 & 一 & - & - \\
\hline Mallomonas & - & - & -- & -- & - & - & -- & 1 & -- & - & - & -- & - & - & - & - & - \\
\hline Rhodomonas & - & - & 1 & - & - & - & - & - & - & - & - & - & - & - & - & - & - \\
\hline Trachelomonas & - & $\therefore$ & - & - & 3 & 1 & 1 & -- & - & - & 3 & - & 1 & - & 2 & - & - \\
\hline Uroglenopsis & - & -- & - & - & - & -- & - & - & - & - & - & 一 & 1 & - & 1 & - & - \\
\hline
\end{tabular}


Table 7.--Dominant and codominant algal genera in phytoplankton samples of 17 study lakes in Fagar-Continued

\begin{tabular}{|c|c|c|c|c|c|c|c|c|c|c|c|c|c|c|c|c|c|c|}
\hline \multirow[b]{2}{*}{ Genera } & \multicolumn{18}{|c|}{$\begin{array}{l}\text { Number of occurrences in which each genus comprised at } \\
\text { least } 15 \text { percent of the phytoplankton population }\end{array}$} \\
\hline & 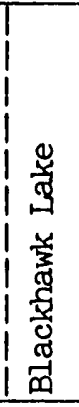 & 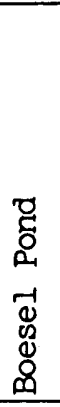 & 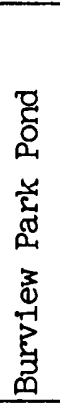 & 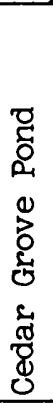 & 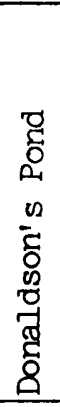 & 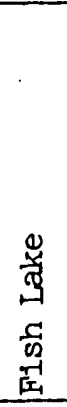 & 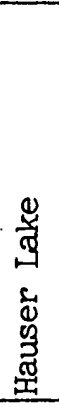 & 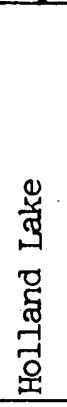 & 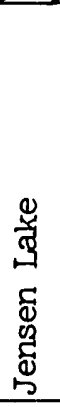 & 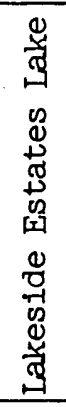 & 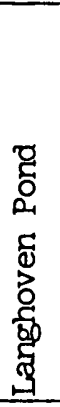 & 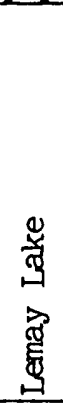 & 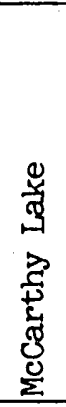 & 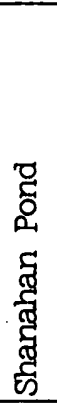 & 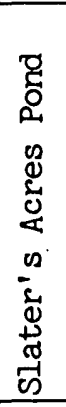 & 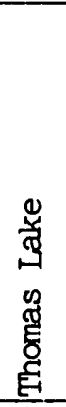 & 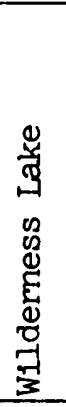 & 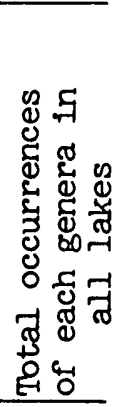 \\
\hline \multicolumn{19}{|c|}{ Green algae } \\
\hline Ank1strodesmus & - & $=$ & - & - & 1 & - & - & - & - & - & 1. & - & 1 & - & - & - & - & 3 \\
\hline Chlamydomonas & - & - & - & - & $\overline{1}$ & 2 & 1 & - & - & - & 2 & - & - & $i$ & 1 & - & - & 8 \\
\hline Chlorella & - & - & - & - & - & - & 1 & - & - & - & - & - & - & - & - & - & 1 & 2 \\
\hline Coelastrum & - & - & - & - & 1 & - & - & - & - & - & - & - & - & - & - & - & - & 1 \\
\hline Crucigenta & - & 一 & - & - & - & - & - & - & 一 & 一 & 1 & - & - & - & - & - & - & 1 \\
\hline Dictosphaerium & - & - & - & - & - & 2 & - & - & 3 & - & - & - & - & - & 1 & - & - & 6 \\
\hline Gleoactinum & - & - & - & $\ldots$ & - & - & - & - & 1 & - & - & - & - & - & - & - & - & 1 \\
\hline Kirchneriella & - & - & - & - & - & - & - & - & - & 1 & - & - & - & - & - & - & - & 1 \\
\hline Micractinium & - & - & - & - & 1 & - & - & - & - & - & 2 & - & - & - & - & - & - & 3 \\
\hline Docystis & - & - & - & - & - & - & 1 & - & - & - & -- & - & - & 2 & - & - & - & 3 \\
\hline Pandorina & - & - & - & - & - & - & 1 & - & - & - & - & - & - & - & - & - & - & 1 \\
\hline Scenedesmus & -- & -- & - & - & - & - & -- & - & - & 1 & 1 & - & - & 3 & 2 & - & 1 & 8 \\
\hline Schroederia & 1 & - & 1 & - & 1 & - & - & - & - & - & - & - & - & - & - & - & - & 3 \\
\hline Serenastrum & - & - & - & - & - & - & - & 1 & - & - & - & - & - & - & - & -- & - & 1 \\
\hline Sphaerocystis & - & - & - & - & - & 1 & - & - & 1 & 1 & - & - & 1 & 1 & - & - & - & 5 \\
\hline Volvox & 1 & - & - & - & - & - & - & -- & - & - & - & - & - & - & - & -- & - & 1 \\
\hline \multicolumn{19}{|c|}{ Yellow-brown algae } \\
\hline Crysococcus & - & - & - & - & - & 1 & - & - & 一 & - & - & - & - & - & - & - & - & 1 \\
\hline Dinobryon & - & - & -- & - & -- & 2 & - & 4 & -- & - & - & - & - & - & - & - & - & $\overline{6}$ \\
\hline Ochromonas & - & - & - & - & 1 & 1 & 1 & 2 & - & - & - & 1 & - & - & 2 & - & - & 8 \\
\hline Uroglena & - & -- & - & - & - & - & - & $\overline{1}$ & -- & - & -- & - & - & - & - & - & - & 1 \\
\hline \multicolumn{19}{|l|}{ Number of genera } \\
\hline found in each lake & 12 & 4 & 9 & 7 & 12 & 12 & 12 & 10 & 9 & 11 & 14 & 10 & 12 & 12 & 14 & 6 & 8 & \\
\hline
\end{tabular}




\section{SUMMARY AND CONCLUSIONS}

Water-quality characteristics of 17 lakes and ponds in the city of Eagan were described from data collected in 1972 through 1978. The data showed that differences in water quality between lakes were related to differences in the percentage of urbanization. However, water-quality variations within each lake during the study were affected more by climatic variations than by land-use changes during that period. Measurable increases in chloride and phosphorus concentrations were observed in many lakes during the drought of 1976-77, but concentrations in most have since recovered to pre-drought levels.

Depth was an important factor controlling lake quality. The two deepest lakes, Holland and Fish, were the least eutrophic lakes studied. These lakes limit continuous recycling of nutrients from bottom materials to surface waters by thermal stratification and entrapment in the hypolimion. Owing to their depth and lower algal populations, winter oxygen conditions in about the upper two meters of Holland and Fish seem to be sufficient to support a small fishery.

The other 15 lakes studied were all less than 10 feet deep and frequently mix during open water. Oxygen conditions in most of these lakes are probably low under ice cover most years, and so, fishery potential is virtually eliminated in some and minimal in others. The nutrient levels in all 15 lakes indicate highly eutrophic conditions, because of the combined effects of high loading and recycling of nutrients. However, chlorophyll a concentrations in the shallower lakes ( 1.5 to 5.0 feet) do not always indi= cate highly eutrophic systems. Winterkill of planktivorous fish in these lakes probably results in heavy grazing of algae by zooplankton, which in turn results in lower than expected chlorophyll a concentrations. Thus, a third trophic indicator, secchi disk transparency, is usually bottom-limited in these shallower lakes.

Dissolved solids, alkalinity, and chloride concentrations varied most in lakes with urbanized watersheds and in lakes less than 6 feet deep. Storm-sewer outlets are necessary for controlling maximm lake levels in highly urbanized watersheds of the Eagan lakes. Three lakes, which have outlets and flush from about 2 to 25 times per year, undergo the most severe fluctuations in lake chemistry. Chloride concentrations in excess of 30 $\mathrm{mg} / \mathrm{L}$ were common in spring and early summer. However, concentrations less than $5 \mathrm{mg} / \mathrm{L}$ were common in late summer and fall owing to flushing by sumer rains. In contrast, chloride concentrations in certain lakes without outlets were either quite stable or increased during the study. The increases were caused in part by urbanization and were intensified by the 1976-77 drought.

As in many other lake studies in Minnesota, phosphorus was the single most critical chemical constituent in controlling the trophic state of the 
Eagan lakes (based on chlorophyll a and transparency data). Therefore, several attempts were made to use avallable models and to develop other models for predicting changes in phosphorus concentrations resulting from changes in land use (phosphorus loading). Of the many models tested, three phosphorus-prediction models developed during the study are applicable to shallow (less than about 12 feet), nonstratifying lakes and ponds, provided that they recelve munoff typical of the Eagan area. One model, derived from a multiple-regression analysis, uses the percentage of the watershed developed and the lake volume to predict phosphorus concentrations. The other models use phosphorus settling and flushing, or retention coefficients, to predict phosphorus concentrations from an estimated annual phosphorus load. The data base was not sufficient to select an appropriate model to predict the effects of future urban loading in the deeper lakes.

In addition to controlling the concentrations of dissolved solids, chloride, and alkalinity, flushing apparently controls phosphorus buildup In some of the Eagan lakes. Despite the in-lake benefits of flushing, the downstream effects of flushed-out phosphorus may not be beneficial. However, most of the flushed-out phosphorus is in the total form (that is, algal cells and other suspended material). Therefore, use of filtering devices at lake inlets or outlets (such as wetlands or porous dikes with tile drainage) may be effective in reducing phosphoms loads within the storm-sewer system, at least for certain flows. Lake volume is also a controlling factor by providing for dilution of input loads, especially in early phases of urbanization of the drainage basin. Maximization of lake depth or surface area is a consideration in the design of the storm-sewer system. Some degree of algal control may also be possible by artificial control of bottom-feeder and planktivorous fish (Shapiro, 1979).

According to the Eagan Comprehensive Storm Sewer Plan (Bonestroo and others, 1978) F1sh Lake will eventually recelve a considerably larger amount of urban munoff than at present (1979), suggesting continued water-quality monitoring of this lake. The water-quality impact of this planned development might be minimized if future storm-sewer inlets and outlets are designed to limit additional phosphorus loading to Fish Lake and to preserve the beneficial effects of thermal stratification.

Future studies of the Eagan lakes might concentrate on determining the management practices, both natural and artificial, that are most effective in reducing nutrient loads or recycling and yet fit within geomorphic and economic constraints. Other factors which were not quantified in this study, but which are suspected to be influencing the present analysis of nutrient budgets of these lakes include (1) recycling of phosphorus from bottom sed1ments owing to the shallow, nonstratifying nature of the lakes, (2) effects of Iittoral aquatic vegetation on phosphorus uptake and settling, (3) effects on phosphorus settling of zooplankton grazing of algae, (4) actual rather than estimated phosphorus loads delivered to each lake system, and (5) effects of ground-water flux through the lake systems. 


\section{REFERENCES}

Barr, A. J., Goodnight, J. H., Sall, J. P., and Helwig, J. T., 1976, A user's guide to SAS 76: SAS Institute Incorporated, Raleigh, North Carolina, 329 p.

Bonestroo, O. G., Rosene, R. W., Anderlik, J. C., and Associates, Incorporated, 1972, Storm sewer master plan, Eagan, Minnesota: unpublished consulting report, $187 \mathrm{p}$.

1978, Comprehensive storm sewer plan, Eagan, Minnesota: unpublished consulting report, $43 \mathrm{p}$.

Brown, Eugene, Skougstad, M. W., and Fishman, M. J., 1979, Methods for collection and analysis of water samples for dissolved minerals and gases: U.S. Geological Survey Techniques of Water-Resources Investigations, book 5, chap. Al, $160 \mathrm{p}$.

Carlson, R. E., 1977, A trophic state index for lakes: Limnology and Oceanography, v. 22, no. 2, p. 361-369.

Chapra, S. C., and Tarapchak, S. J., 1976, A chlorophyll a model and its relationship to phosphorus loading plots for lakes: WaterResources Research, v. 12, no. 6, p. 1260-1264.

Dillon, P. J., and Rigler, F. H., 1975, A simple method for predicting the capacity of a lake for development based on lake trophic status: Journal of F1shery Research Board of Canada, v. 32, p. 1519-1531.

Goerlitz, D. F., and Brown, Eugene, 1972, Methods for analysis of organic substances in water: U.S. Geological Survey Techniques of WaterResources Investigations, book 5, chap. A3, $40 \mathrm{p}$.

Greeson, P. E., and others, 1977, Methods for collection and analysis of aquatic biological and microbiological samples: U.S. Geological Survey Techniques of Water-Resources Investigations, book 5, chap. A4, $165 \mathrm{p}$.

Have, M. R., 1975, Some limnological aspects of 20 selected lakes in Eagan and Apple Valley, Minnesota: U.S. Geological Survey Open-File Report 75-528, 56 p.

Jones, J. R., and Bachmann, R. W., 1976, Prediction of phosphorus and chlorophyll levels in lakes: Joumal of Water Pollution Control Federation, v. 48, no. 9, p. 2176-2182. resources outlook for the Minneapolis-St. Paul metropolitan area, Minnesota: Metropolitan Council of the Twin Cities Area, $219 \mathrm{p}$.

1978, Trophic status of Iowa lakes in relation to origin and glacial geology: Hydrobiologia, v. 57, no. 3, p. 267-273. 
Norvitch, R. F., Ross, T. G., and Brietkrietz, Alex, 1973, Water resources outlook for the Minneapolis-St. Paul metropolitan area, Minnesota: Metropolitan Council of the Twin Cities Area, $219 \mathrm{p}$.

Oberts, Gary, and Jouseau, Marcel, 1979, Water pollution from nonpoint sources-An assessment and recommendations: Metropolitan Council of the Twin Cities Area publication No. 62-72-008, 194 p.

Reckhow, K. H., 1977, Phosphorus models for lake management: unpublished Ph. D. dissertation, Harvard University.

1979, Quantitative techniques for the assessment of lake quality: U.S. Environmental Protection Agency, EPA-440/5-79-015, 146 p.

Sakamoto, M., 1966, Primary production by phytoplankton cormunity in some Japanese lakes and its dependence on lake depth: Archiv. f. Hydrobiologia, v. 62, p. 1-28.

Shapiro, J., 1979, The need for more biology in lake restoration, in Lake restoration, proceedings of a national conference, August 2224, 1978, Minneapolis, Minn.: U.S. Environmental Protection Agency Publication 440/5-79-001, p. 161-167.

Skougstad, M. W., and others, 1978, Methods for analysis of inorganic substances in water and fluvial sediments: U.S. Geological Survey Techniques of Water-Resources Investigations, Book 5, Chapter A1, $1005 \mathrm{p}$.

Slack, K. V., Averett, R. C., Greeson, P. E., and Lipscomb, R. G., 1973, Methods for collection and analysis of aquatic biological and microbiological samples: U.S. Geological Survey Techniques of WaterResources Investigations, Book 5, Chapter A4, 165 p.

Smith, V. H., 1979, Heine Pond, Dakota County, Minnesota: Current status and projected changes in water quality following inputs of storm runoff from a proposed stormwater drainage system: Unpublished report, on file with Bonestroo, Rosene, Anderlik, and Associates, St. Paul, Minnesota, 15 p.

U.S. Environmental Protection Agency, 1974, The relationships of phosphorus and nitrogen to the trophic state of northeast and northcentral lakes and reservolrs: National Eutrophication Survey Working Paper no. 23, December 1974.

University of Minnesota, Department of Soil Science, 1975, Soll landscapes and geomorphic regions - Twin Cities metropolitan area sheet: Map published as part of the Minneapolis-St. Paul Regional Area Level B study. 
Vollenwelder, R. A., 1976, Advances in defining critical loading levels for phosphorus in lake eutrophication: Memorie dell Istituto Italiana di Idrobiologia, v. 33, p. 53-83.

Walker, W. W., Jr., 1977, Some analytical methods applied to lake waterquality problems: unpublished Ph.D dissertation, Harvard University.

Wetzel, R. G., 1975, Limnology: W. B. Saunders Company, Philadelphia, Penn., $743 \mathrm{p}$.

Wright, H. E., Jr., 1972, Quaternary history of Minnesota, in Geology of Minnesota - A centennial volume: P. K. Sims, and G. B. Morey, eds., Minnesota Geological Survey, p. 515-546.

\U.S. GOVERMMENT PRINTING OFFICE: 1980--669252/55 